\title{
1. INTRODUCTION AND EXPLANATORY NOTES, LEG 43 DEEP SEA DRILLING PROJECT
}

\author{
Brian E. Tucholke, Lamont-Doherty Geological Observatory of Columbia University, Palisades, New York \\ and \\ Peter R. Vogt, Naval Research Laboratory, Washington D.C.
}

\section{SCIENTIFIC GOALS AND PLANNING}

Leg 43 was planned to examine a wide variety of geological problems at numerous sites in the deep western North Atlantic basin. A variety of objectives were to be addressed on Leg 43, the principal emphasis being concentrated on, but not limited to, the following:

1) To core continuously through the major acoustic horizons (" $A$ ", $A^{*}$, and $\beta$ ) at several locations in the basin to establish the lithostratigraphic and chronostratigraphic correlations of the reflectors, and to determine if variations in these correlations could be related to lateral changes in acoustic character of the reflectors.

2) To investigate the sedimentary development of the North American basin with particular emphasis on (a) the age and nature of presumed calcareous sediments below the most seaward occurrence of Horizon $\beta$ on the western Bermuda Rise, (b) the seaward limit of Lower Cretaceous black clays in the western North Atlantic, the cause of the black-clay deposition, and the depth limits within which the clays were deposited, (c) the age, distribution and origin of the multicolored clays overlying the black clays, (d) the sources and distribution of the markedly siliceous Paleogene sediments on the Bermuda Rise, and (e) the role of surface/abyssal currents and surface productivity patterns in the Mesozoic and Cenozoic development of the sedimentary record.

3) To recover sediments containing late Mesozoic and Cenozoic fossils for biostratigraphic, paleobiogeographic, and paleoceanographic studies.

4) To recover samples of basaltic basement from the smooth crest of the basement ridge associated with the high-amplitude " $J$ '" magnetic anomaly north of the New England seamounts and determine whether the anomaly is accompanied by unusual basement composition and magnetic properties.

5) To examine the age and nature of volcanism on Bermuda and along the New England seamount chain, in order to test ideas on volcanio origin such as the "hotspot" hypothesis, and to examine volcaniclastic lithofacies and assess the role of volcanic sources for certain North Atlantic sediments.

6) To determine the age of basement in the central part and at the young end (" $J$-anomaly") of the Keathley ( $M$-series) magnetic anomalies, and in the older part of the Cretaceous "magnetic quiet zone," in order to better calibrate the $M$-series (Keathley) reversal chronology and the sea-floor-spreading history of the North Atlantic.
The primary sites that were proposed for drilling on Leg 43 are listed in Table 1; several alternate sites are not included in the table. In reviewing the sites and objectives for Leg 43, the Atlantic Advisory Panel decided that a maximum of about 8 days be devoted to seamount drilling and that the remaining time be used to examine sedimentary and crustal problems.

\section{SUMMARY OF SITES DRILLED}

We drilled six holes at six sites (382-387) on Leg 43 (Table 2, Figure 1). All of the sites except Site 383 met our minimum objectives and provided unexpected and exciting new information on the geologic history of the western North Atlantic basin.

On the basis of Leg 43 drilling results and subsequent study of seismic profiler data recorded in the western North Atlantic, several reflectors comprising the Horizon- $A$ complex have been individually identified and correlated with distinctive lithofacies. These reflectors, termed Horizons $A^{C}, A^{T}, A^{V}$, and $A^{U}$, are included in the following site summaries and are discussed in detail by Tucholke (this volume).

\section{Site 382-Nashville Seamount}

At Site 382 (proposed Hole 43-2) the sedimentary section above the buried eastern flank of Nashville Seamount was sampled down to a sub-bottom depth of 520.5 meters (Figure 2). The hole bottomed in coarse volcaniclastic breccia attributed to volcanism on Nashville Seamount. Slow progress in penetrating the breccia, combined with time restrictions, led us to abandon the hole at this level.

The sedimentary sequence at Site 382 can be summarized as follows (with average sedimentation rates in parentheses): 0 to 232 meters sub-bottom depth -Quaternary clays, silty clays, and silts $(120 \mathrm{~m} / \mathrm{m} . \mathrm{y}$.); 232 to 352 meters-mid-Pliocene to lower Miocene hemipelagic clays $(6 \mathrm{~m} / \mathrm{m} . \mathrm{y}) ;$.352 to 385 meters - Campanian varicolored (volcanogenic) silty clays $(>30$ $\mathrm{m} / \mathrm{m} . \mathrm{y}$.); 385 to 520.5 meters-lower Campanian volcanogenic clay, silty clay, marly limestone, and volcaniclastic breccia overlying volcanogenic claystones and sandstones over breccia ( $>30 \mathrm{~m} / \mathrm{m} . \mathrm{y}$.) A hiatus spanning about 45 to 50 m.y. occurs between lower Miocene sediments. The rapidly deposited Quaternary silty clays are a succession of distal turbidites, and they indicate that the Sohm Abyssal Plain was not developed this far south until early Pleistocene. The 50-m.y. hiatus probably reflects some combination of current erosion and 
TABLE 1

Summary of Proposed Sites for Leg 43, Western North Atlantic

\begin{tabular}{|c|c|c|c|c|c|c|}
\hline $\begin{array}{l}\text { Proposed- } \\
\text { Hole No. }\end{array}$ & Area & Coordinates & $\begin{array}{l}\text { Water } \\
\text { Depth } \\
\text { (m) }\end{array}$ & $\begin{array}{l}\text { Sediment } \\
\text { Penetration } \\
\text { (m) }\end{array}$ & Priority & Major Objectives \\
\hline $43-1$ & $\begin{array}{l}\text { Sohm Abyssal Plain } \\
\text { ( } J \text {-Anomaly Ridge) }\end{array}$ & $\begin{array}{l}38^{\circ} 29^{\prime} \mathrm{N} \\
54^{\circ} 19^{\prime} \mathrm{W}\end{array}$ & 5325 & 850 & 1 & $\begin{array}{l}\text { Age and nature of basement, tectonic history, } \\
\text { sedimentation history }\end{array}$ \\
\hline $43-2$ & Nashville Seamount & $\begin{array}{l}34^{\circ} 25^{\prime} \mathrm{N} \\
56^{\circ} 31^{\prime} \mathrm{W}\end{array}$ & 5525 & 650 & 1 & $\begin{array}{l}\text { Age of seamount volcanism, sedimentation } \\
\text { history }\end{array}$ \\
\hline $43-3$ & Gilliss Seamount & $\begin{array}{l}35^{\circ} 39^{\prime} \mathrm{N} \\
58^{\circ} 30^{\prime} \mathrm{W}\end{array}$ & 5100 & 300 & 2 & Age of seamount volcanism \\
\hline $43-5 \mathrm{~A}$ & $\begin{array}{l}\text { Small seamount east of } \\
\text { Vogel Seamount }\end{array}$ & $\begin{array}{l}37^{\circ} 03^{\prime} \mathrm{N} \\
59^{\circ} 41^{\prime} \mathrm{W}\end{array}$ & 5150 & 1200 & $\begin{array}{c}1 \\
\text { (alternate) }\end{array}$ & $\begin{array}{l}\text { Age of seamount volcanism, sedimentation } \\
\text { history }\end{array}$ \\
\hline $43-6$ & Gosnold Seamount & $\begin{array}{l}37^{\circ} 52^{\prime} \mathrm{N} \\
62^{\circ} 24^{\prime} \mathrm{W}\end{array}$ & 5000 & 1050 & 1 & $\begin{array}{l}\text { Age of seamount volcanism, sedimentation } \\
\text { history of basin }\end{array}$ \\
\hline $43-7$ & Northwest Bermuda Rise & $\begin{array}{l}35^{\circ} 08^{\prime} \mathrm{N} \\
66^{\circ} 53^{\prime} \mathrm{W}\end{array}$ & 5125 & 950 & 1 & $\begin{array}{l}\left.\text { Age and nature of reflectors (dual } A, A^{*}, \beta\right), \\
\text { paleosedimentation and circulation, age of } \\
\text { basement }\end{array}$ \\
\hline $43-8$ & Southeast Bermuda Rise & $\begin{array}{l}31^{\circ} 10^{\prime} \mathrm{N} \\
64^{\circ} 15^{\prime} \mathrm{W}\end{array}$ & 4825 & 940 & 1 & $\begin{array}{l}\text { Age and nature of reflectors (dual } A, A^{*} \text { ), age } \\
\text { of Bermudan volcanism, basement age }\end{array}$ \\
\hline $43-9$ & Western Bermuda Rise & $\begin{array}{l}32^{\circ} 19^{\prime} \mathrm{N} \\
67^{\circ} 42^{\prime} \mathrm{W}\end{array}$ & 5150 & 900 & 1 & $\begin{array}{l}\text { Age and nature of reflectors (dual } A, A^{*}, \beta \text { ), } \\
\text { basement age, paleosedimentation, and cir- } \\
\text { culation }\end{array}$ \\
\hline $43-10$ & Westernmost Bermuda Rise & $\begin{array}{l}33^{\circ} 04^{\prime} \mathrm{N} \\
69^{\circ} 42^{\prime} \mathrm{W}\end{array}$ & 5400 & 750 & 1 & $\begin{array}{l}\text { Age and nature of reflectors (single } A \text {, no } A^{*} \text {, } \\
\beta \text { ), paleocirculation and sedimentation, age of } \\
\text { basement }\end{array}$ \\
\hline $43-11$ & Lower Continental Rise & $\begin{array}{l}34^{\circ} 09^{\prime} \mathrm{N} \\
71^{\circ} 34^{\prime} \mathrm{W}\end{array}$ & 5100 & 1000 & 2 & $\begin{array}{l}\text { Age and nature of Horizon } A \text { and diffuse } \\
\text { reflector above } A \text {, Paleogene sedimentation } \\
\text { dynamics }\end{array}$ \\
\hline $43-12$ & Upper Continental Rise & $\begin{array}{l}38^{\circ} 24^{\prime} \mathrm{N} \\
71^{\circ} 32^{\prime} \mathrm{W}\end{array}$ & 2800 & 250 & 1 & $\begin{array}{l}\text { Sample gas-hydrates with pressurized core } \\
\text { barrel }\end{array}$ \\
\hline
\end{tabular}

TABLE 2

Drilling and Coring Summary, DSDP Leg 43, 1975

\begin{tabular}{|c|c|c|c|c|c|c|c|c|c|c|c|}
\hline Site & $\begin{array}{l}\text { Dates } \\
\text { Occupied }\end{array}$ & $\begin{array}{l}\text { Hours } \\
\text { on Site }\end{array}$ & $\begin{array}{l}\text { Latitude, } \\
\text { Longitude }\end{array}$ & $\begin{array}{c}\text { Water } \\
\text { Depth } \\
\text { (m) }\end{array}$ & $\begin{array}{l}\text { Penetration } \\
\quad(\mathrm{m})\end{array}$ & $\begin{array}{l}\text { No. of } \\
\text { Cores }\end{array}$ & $\begin{array}{l}\text { Cored } \\
(\mathrm{m})\end{array}$ & $\begin{array}{l}\text { Recovered } \\
\text { (m) }\end{array}$ & $\begin{array}{l}\text { Recovered } \\
(\%)\end{array}$ & $\begin{array}{l}\text { Oldest } \\
\text { Sediment }\end{array}$ & $\begin{array}{l}\text { Deepest } \\
\text { Unit }\end{array}$ \\
\hline 382 & July 5-9 & $901 / 2$ & $\begin{array}{l}34^{\circ} 25.04^{\prime} \mathrm{N} \\
56^{\circ} 32.25^{\prime} \mathrm{W}\end{array}$ & 5527 & 520.5 & 25 & 232.2 & 163.4 & 70.4 & $\begin{array}{l}\text { Lower Campanian } \\
\text { - ?Santonian }\end{array}$ & $\begin{array}{l}\text { Volcaniclastic } \\
\text { breccia }\end{array}$ \\
\hline 383 & July $10-12$ & 36 & $\begin{array}{l}39^{\circ} 14.88^{\prime} \mathrm{N} \\
53^{\circ} 21.18^{\prime} \mathrm{W}\end{array}$ & 5267 & 120.3 & 2 & 19.1 & 4.9 & 26.0 & Pleistocene & Sand \\
\hline 384 & July $12-15$ & $541 / 2$ & $\begin{array}{l}40^{\circ} 21.65^{\prime} \mathrm{N} \\
51^{\circ} 39.80^{\prime} \mathrm{W}\end{array}$ & 3910 & 330.3 & 22 & 195.3 & 110.5 & 57.0 & $\begin{array}{l}\text { Upper Barremian - } \\
\text { lower Aptian }\end{array}$ & Basalt \\
\hline 385 & July $18-20$ & 64 & $\begin{array}{l}37^{\circ} 22.17^{\prime} \mathrm{N} \\
60^{\circ} 09.45^{\prime} \mathrm{W}\end{array}$ & 4956 & 392.9 & 24 & 227.6 & 63.4 & 27.9 & $\begin{array}{l}\text { Lower Maestrichtian } \\
\text { or older }\end{array}$ & $\begin{array}{l}\text { Volcaniclastic } \\
\text { breccia }\end{array}$ \\
\hline 386 & July $24-31$ & 166 & $\begin{array}{l}31^{\circ} 11.21^{\prime} \mathrm{N} \\
64^{\circ} 14.94^{\prime} \mathrm{W}\end{array}$ & 4783 & 973.8 & 66 & 626.7 & 438.2 & 69.9 & Lower Albian & Basalt \\
\hline 387 & Aug. 1-7 & 138 & $\begin{array}{l}32^{\circ} 19.20^{\prime} \mathrm{N} \\
67^{\circ} 40.00^{\prime} \mathrm{W}\end{array}$ & 5118 & 794.5 & 50 & 467.9 & 178.2 & 38.1 & $\begin{array}{l}\text { Upper Berriasian - } \\
\text { lower Valanginian }\end{array}$ & Basalt \\
\hline Total & $(22$ & $\begin{array}{l}549 \\
\text { days } 21\end{array}$ & & & 3132.3 & 189 & 1768.8 & 958.6 & 54.2 & & \\
\hline
\end{tabular}

local slumping off the seamount's flanks. Volcanic activity on Nashville Seamount was already in progress in the lower Campanian-?Santonian and continued to produce coarse volcaniclastic debris throughout the Campanian. The volcanism explains the relatively high sedimentation rate $(30 \mathrm{~m} / \mathrm{m} . \mathrm{y}$.$) during this time. High$ vesicularity of basaltic clasts in the breccias indicates that the summit of Nashville Seamount was close to sea level, or even emergent, during the ?Santonian to Campanian. Finer grained deposits and lower sedimentation rates during the late Campanian suggest the waning stages of local volcanic activity or introduction of 


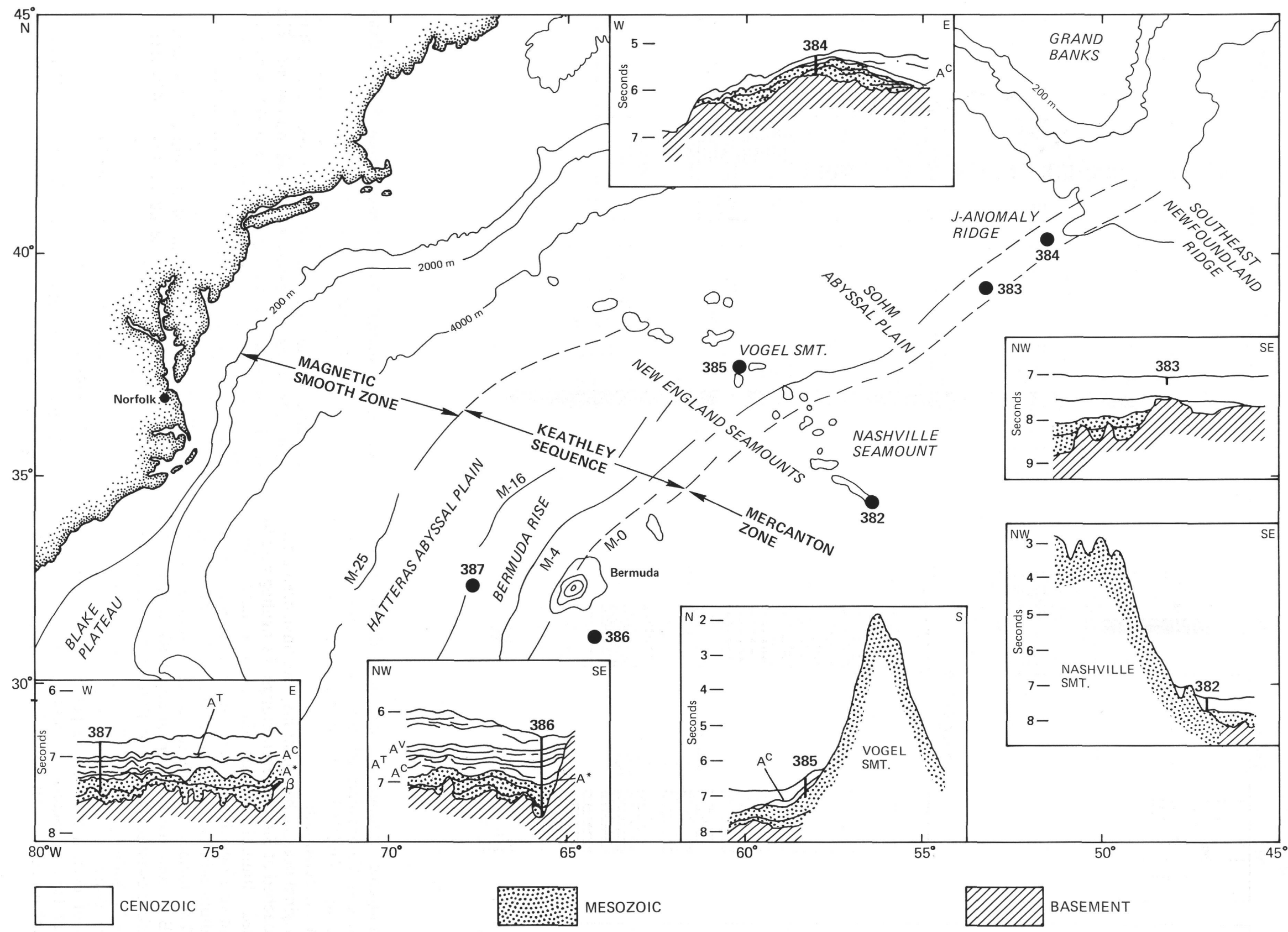

Figure 1. Locations of Leg 43 sites in western North Atlantic; locations of some of the anomalies in the Keathley sequence (M-series) are shown. Insets show simplified interpretations of profiler records across sites (depths in seconds two-way travel time). 

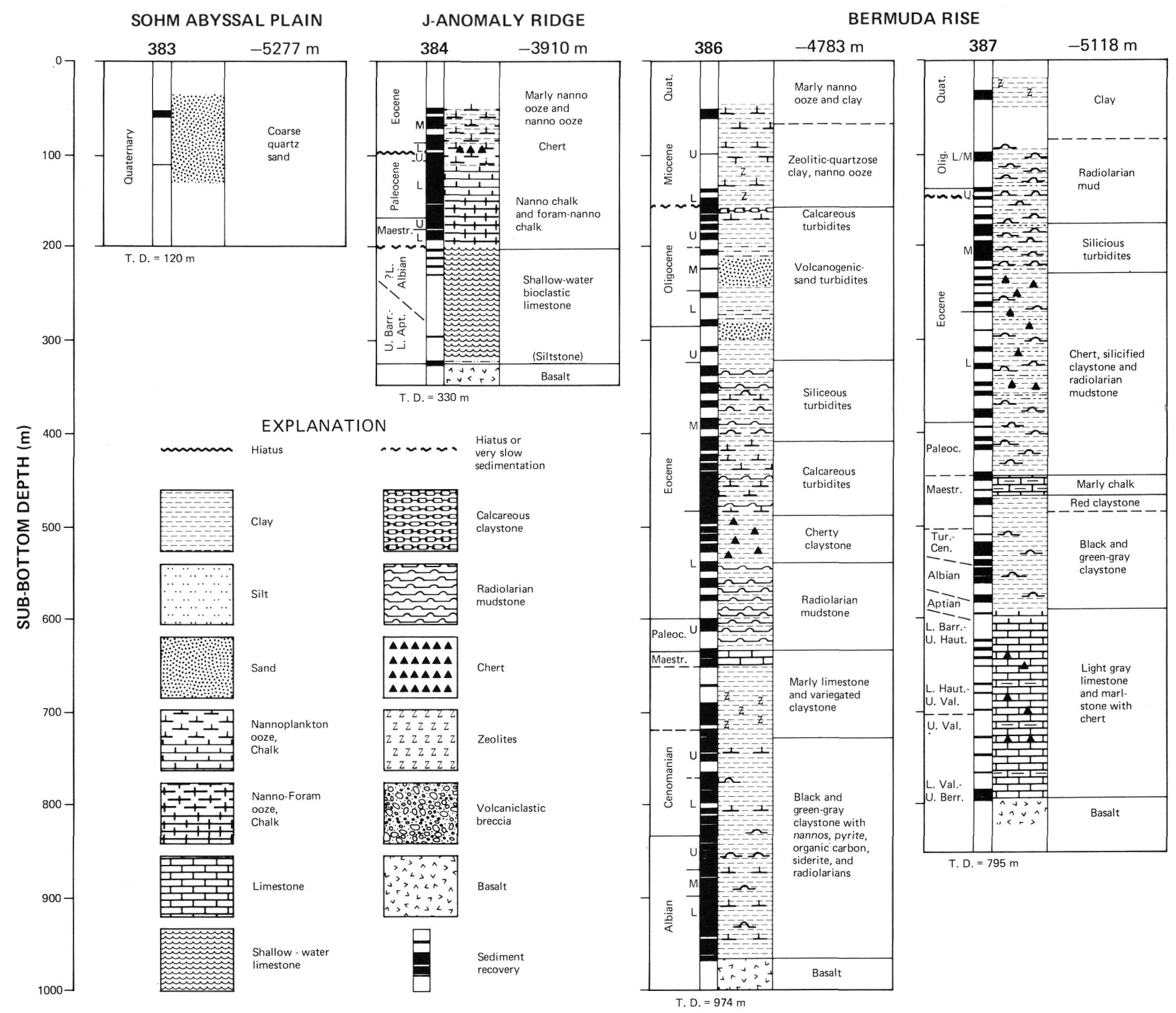

Figure 2. Summary of DSDP Leg 43 drilling results.

volcanogenic sediments from more distant sources. Numerous Campanian ash horizons encountered 450 $\mathrm{km}$ away at DSDP Site 10 may have been derived from Nashville Seamount.

Original oceanic basement may not have been closely approached at Site 382 even though the drilling rate increased dramatically for the deepest core. When measured along the flow lines of plate motion, Site 382 lies about midway between anomaly $M-0$ and anomaly 34. The former is believed to date from about 108 m.y.B.P. and the latter from about 80 m.y.B.P. We therefore estimate that about 12 to 16 m.y. elapsed between formation of original basement and deposition of the lowermost breccia that we cored. At sedimentation rates of even a few meters per m.y., there must be several tens of meters of sediments between oceanic basement and the deepest level penetrated at Site 382 .
Site 383- $\boldsymbol{J}$-Anomaly Ridge Beneath Sohm Abyssal Plain

Site 383 (proposed Hole 43-1) was drilled 120 meters into the Sohm Abyssal Plain before deteriorating hole conditions and the risk of losing the bottom-hole assembly in caving sands forced abandonment. The single core that was recovered consists of 4.9 meters of graded Pleistocene sand. The grading is undoubtedly an artifact produced by flushing of sand into the core barrel during a break in circulation. The primary target of Site 383 , basaltic basement of the buried $J$-Anomaly Ridge, was estimated to lie about 400 to 450 meters below the sea floor.

\section{Site 384-J-Anomaly Ridge on Grand Banks Continental Rise}

Stymied by the sands of the Sohm Abyssal Plain, we decided to drill into the $J$-Anomaly Ridge where it 
NASHVILLE SMT.
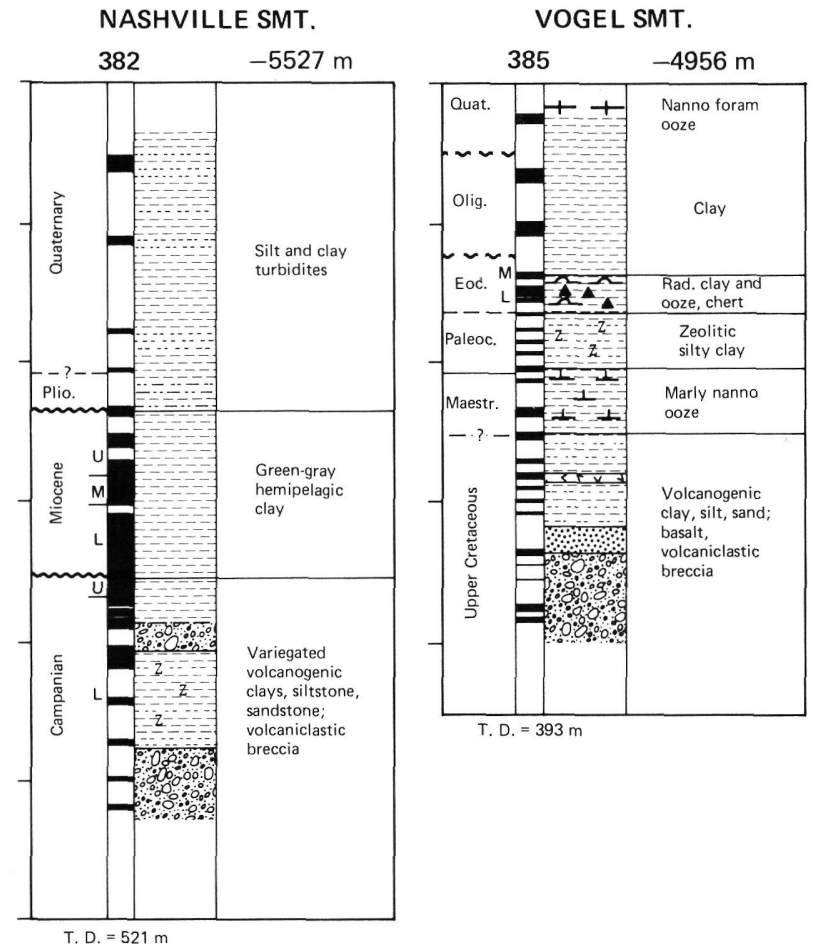

Figure 2. (Continued).

emerges above the lower continental rise south of the Grand Banks. The $\mathbf{3 3 0 . 3}$ meter hole bottomed in altered vesicular basalt which plugged the bit and jammed the core barrel in the drill sting. We anticipated that a prominent reflector within the acoustically nonlaminated sediments covering the ridge might correlate with Eocene cherts (Horizon $A^{C}$ ), which previously had been found only to the south of the Sohm Abyssal Plain. Reduced drilling rates and recovery of chert fragments and silicified limestone of early Eocene age at the level of the reflector confirmed this evaluation. The section drilled consists of the following major lithofacies (top to bottom): (1) An uncored sedimentary section between 0 and 50 meters sub-bottom, which a nearby piston core suggests would consist of Neogene calcareous oozes and clay. (2) Marly nannofossil ooze, nannofossil ooze, nannofossil chalk, and foraminifer nannofossil chalk of middle Eocene to early Maestrichtian age $(50-200 \mathrm{~m})$.

This calcareous unit contains well-preserved foraminifers and nannoplankton in a continuous sequence across the Cretaceous/Tertiary boundary, as well as an excellent assemblage of radiolarians down to the lower Paleocene. A significant $(\sim 10$ m.y. $)$ hiatus is present at the Paleocene/Eocene boundary. High carbonate content $(50-100 \%)$ and nearly uniform sedimentation rates $\left(0.5 \mathrm{~g} / \mathrm{cm}^{2} / \mathrm{k} . \mathrm{y}\right.$. for Cretaceous and Paleocene, $1.5 \mathrm{~g} / \mathrm{cm}^{2} / \mathrm{k} . \mathrm{y}$. for Eocene) indicate deposition in a quiescent environment, probably in relatively shallow water, well above the CCD. We found no evidence for the hypothesized dramatic rise in the CCD at the Maestrichtian/Paleocene boundary. (3) Upper Barremian to lower Albian shallow-water bioclastic limestones with minor interbedded calcareous clays $(200-325 \mathrm{~m})$, indicating more than 4000 meters subsidence for this part of the $J$-Anomaly Ridge in the last 105 m.y. A major hiatus separates the Lower Cretaceous reef debris from the overlying Maestrichtian pelagic chalks. (4) The bioclastic limestones are underlain below 325 meters by highly vesicular, weathered basalt, apparently formed as a subaerial or shallow-water flow. An upper Barremain/lower Aptian age for the immediately overlying sediment indicates that anomaly $M-2$ is at least 112 to $118 \mathrm{~m}$.y. old. A total of 2.36 meters of basalt was cored, probably representing portions of three flows.

\section{Site 385-Vogel Seamount}

Steaming toward proposed Hole 43-6 at Gosnold Seamount, we encountered strong east-flowing Gulf Stream currents which slowed our progress and raised concern as to whether currents would be so strong as to prevent drilling at the site. Accordingly, we altered course toward the south and drilled Site 385 on the northern flank of Vogel Seamount, which is located farther east of the Gulf Stream axis.

Site 385 was drilled 392.9 meters through an acoustically nonlaminated sediment layer and into the underlying volcaniclastic apron of Vogel Seamount. Horizon $A^{C}$ can be traced from beneath the Sohm Abyssal Plain to the drill site, where it occurs $0.2 \mathrm{~s}$ sub-bottom and $0.17 \mathrm{~s}$ above the volcaniclastic apron. A total of 24 cores $(227.6 \mathrm{~m})$ was taken; the low overall recovery $(63.4 \mathrm{~m})$ reflects poor coring performance in cherts and uncemented volcaniclastic sands and gravels.

Formations encountered are: (1) a spot-cored section of Pleistocene to lower Miocene hemipelagic clay overlying (2) continuously cored lower middle to upper lower Eocene clay and chert (138-165 m sub-bottom), which contain a rich and well-preserved radiolarian fauna. Horizon $A^{C}$ correlates with an interval of alternating chert and radiolarian ooze approximately 153 to 165 meters sub-bottom. (3) The section from 165 to 206 meters contains zeolitic silty clay with poorly preserved and unidentified radiolarian assemblages. (4) lower Danian to Maestrichtian marly ooze (206-251 m) overlies (5) volcanogenic sediments older than middle or lower Maestrichtian that continue to 393 meters subbottom. A thin $(18 \mathrm{~cm})$ layer of aphanitic basalt was cored at 283 meters; this may be a sill or flow, although the possibility that the basalt is a displaced boulder cannot be excluded. The deepest volcanic material penetrated is a volcaniclastic breccia very similar to that recovered at Site 382 on Nashville Seamount.

Unfortunately, the volcanogenic unit is unfossiliferous except for a few poorly known and longranging Late Cretaceous benthic foraminifers, and the oldest dated sediment in the hole is the Maestrichtian 
marly ooze above the volcaniclastics. However, we can make some meaningful estimates of the ages from extrapolated and assumed sedimentation rates. If sedimentation rates were fairly uniform in the marly ooze unit, then the top of the volcanogenic debris probably dates from the late Campanian. A good estimate for accumulation rates in the volcanogenic unit may be that determined for similar sediments at Site 382 (30 $\mathrm{m} / \mathrm{m} . \mathrm{y}$.). This places the top of the volcaniclastic breccia at Site 385 within the Campanian. The similar timing thus suggested for the peak volcanic phases at Site 382 and 385 may indicate that they actually are coeval. Unfortunately, neither the biostratigraphic nor radiometric ages at these two sites are sufficiently precise to prove whether the Late Cretaceous volcanism was synchronous or migratory.

\section{Site 386-Central Bermuda Rise}

Site 386 (proposed Hole 43-8) was drilled to a depth of 973.8 meters on the central Bermuda Rise, $140 \mathrm{~km}$ south-southeast of Bermuda. Sixty-six cores were taken, of which the deepest recovered 1.90 meters of altered basalt. Basement age was established as lower Albian on the basis of nannoplankton in the overlying green/black claystones. The section consists of discontinuously cored Pleistocene marly nannofossil ooze and brown clay (0-62 $\mathrm{m}$ sub-bottom), overlying ?Pleistocene to middle Miocene zeolitic clays (62-148 m); continuously cored lower Miocene calcareous turbidites grading downward into Oligocene and upper Eocene volcaniclastic turbidites (148-328 m); middle Eocene siliceous (328-408 m) and calcareous (408-490 m) turbidites overlying middle Eocene to Paleocene radiolarian and cherty mudstones (490-613 m); upper Maestrichtian to upper Cenomanian multicolored claystone (with Maestrichtian limestone) (613-724 m), above Cenomanian to lower Albian black and green-gray claystones (724-964 m); and basalt (cored from 964$974 \mathrm{~m})$.

Deposition was predominantly continuous although highly variable in rate. High rates characterize the Cretaceous sapropelic green-gray and black claystones $(16 \mathrm{~m} / \mathrm{m} . \mathrm{y}$.$) , middle Eocene calcareous/siliceous tur-$ bidites $(33-47 \mathrm{~m} / \mathrm{m} . \mathrm{y}$.$) , upper Paleocene to lower$ Eocene radiolarian mudstones $(5-26 \mathrm{~m} / \mathrm{m} . \mathrm{y}$.), and volcaniclastic turbidites $(19 \mathrm{~m} / \mathrm{m}$.y.). Low rates are indicated for the lower Miocene clays and the Upper Cretaceous multicolored clays.

Volcaniclastic turbidites with shallow-water detritus show that the Bermuda volcanic edifice was emergent by middle or late Eocene time and was leveled by erosion by middle to late Oligocene time. This result corroborates a 33-m.y. published radiometric date on lamprophyric dikes drilled beneath Bermuda. A 30-meter section of upper Cenomanian zeolitic multicolored claystone suggests an earlier volcanic phase about 92 to 96 m.y., possibly correlative with a 90-m.y. radiometric date on igneous rock in the Bermuda drillhole.

Organic carbon analyses in the sapropelic claystones show carbon maxima (11\%) in mid-upper Cenomanian and in lower Albian sediments; this double-peaked character in the mid-Cretaceous correlates with similar carbon distribution in the black clays of Site 105.

The lower Albian age of the basement confirms that crust forming the east flank of the Bermuda Rise was generated at the relatively rapid half rate of about 2.4 $\mathrm{cm} / \mathrm{yr}$.

\section{Site 387-Western Bermuda Rise}

Site 387 (proposed Hole 43-9) penetrated 791.6 meters of sediment and 2.9 meters of basalt. Eight major lithologic units and their approximate subbottom depths are: (1) Pleistocene clay and zeolitic clay (0 $->42 \mathrm{~m})$; (2) upper Oligocene to middle Eocene radiolarian mud (98-175 m); (3) middle Eocene to lower Paleocene siliceous turbidites, silicified claystones, radiolarian mudstone, and chert (175-444 m); (4) Maestrichtian marly chalk (444-469 m); (5) lower Maestrichtian-upper Campanian multicolored claystone (469 - > 479 m); (6) middle Cenomanian/Turonian to Aptian green-gray and black claystone and radiolarian mudstone (> 479-584 m); (7) lower Barremian/upper Hauterivian to upper Berriasian/lower Valanginian chalk and limestone (584-791.9 m); and (8) hypocrystalline phyric basalt $(>791.9 \mathrm{~m})$, which petrographic evidence suggests is a sill.

Trends in sediment accumulation rates are very similar to those at Site 386 , although rates commonly are of different magnitude. Maximum rates of 35-40 $\mathrm{m} / \mathrm{m} . \mathrm{y}$. occurred early in the middle Eocene; the Neocomian limestones were deposited at $10-11 \mathrm{~m} / \mathrm{m} . \mathrm{y}$. and the Lower Cretaceous black clays at 4-5 m/m.y. Minimum rates are observed in the Neogene section and for the Upper Cretaceous multicolored clays.

Nannofossils in calcareous clay overlying the basaltic basement and in sediment inclusions in the basalt date the crust between anomalies $M-15$ and $M-16$ of the Keathley Sequence ( $M$-series) as upper Berriasian/lower Valanginian. If the basalt was intrusive, it was probably emplaced very close to the contemporary Mid-Atlantic Ridge crest.

\section{SUMMARY OF PRINCIPAL RESULTS}

\section{Age and Lithology of Reflectors}

Leg 43 drilling results and subsequent analysis of seismic profiler records allowed discrimination of several reflectors in the group that collectively forms the Horizon- $A$ complex. From the top these are:

1) Horizon $A^{V}$, which is observed adjacent to Bermuda, merges laterally with the Bermuda Pedestal, and locally masks deeper reflectors (especially near Bermuda). The top of this horizon correlates with the top of coarse volcaniclastic turbidites derived from the late Eocene to late Oligocene weathering of Bermudan volcanics.

2) Horizon $A^{T}$, which is widespread west of Bermuda; it usually marks the top of the Horizon- $A$ complex in regions where Horizon $A^{V}$ is absent. This horizon is the middle to upper Eocene top of siliceous turbidites that were deposited beginning in the early 
Eocene; turbidite deposition ceased when uplift raised the Bermuda Rise above the level of the abyssal plain.

3) Horizon $A^{C}$, which is found throughout the North American basin above lower Eocene and older crust. The reflector invariably correlates with upper lower to lower middle Eocene cherts developed in a variety of lithofacies, except at Site $\mathbf{3 8 6}$ where Horizon $A^{C}$ correlates with the top of a series of calcareous turbidites that mask the underlying cherts.

Another reflector of the Horizon- $A$ complex is Horizon $A^{U}$, which is an angular unconformity along the western margin of the basin; it cuts through Horizons $A^{T}, A^{C}$, and older sediments toward the west beneath the lower continental rise, and it began to be eroded by abyssal currents during or after late Eocene time.

Horizon $A^{*}$ normally occurs well beneath the Horizon- $A$ complex, and Ewing and Hollister (1972) suggested that it might match the downward transition from multicolored to black clays. At Sites 386 and 387 we found that $A^{*}$ correlates with an upper Maestrichtian calcareous facies deposited near the top of the multicolored clays.

Horizon $\beta$ was cored at Site 387 , and results confirmed earlier (Sites 101 and 105) correlation of the reflector to the contact between Neocomian limestones and overlying Lower Cretaceous black clays.

\section{Lithofacies and Sedimentary Processes}

Two of the most important controls on sedimentary processes in the North Atlantic probably have been circulation patterns, which affect both biologic productivity and the distribution of sediment, and the position of sea level, which affects dispersal of continental debris to the deep ocean. The following summary of lithofacies and inferred depositional environments from Leg 43 and earlier results emphasizes these controls:

1) Neocomian: high productivity, probably centered along a belt of global circum-equatorial flow through the Tethys, North Atlantic, and Pacific, resulted in deposition of limestones on an oxygenated sea floor, below the present Horizon $\beta$. Siliceous organisms may have been restricted mostly to the central basin higher productivity zone.

2) Barremian/Cenomanian: frequent, but sporadic stagnant conditions in the deep basin resulted in the deposition of black clays in the North Atlantic; the circum-equatorial flow, except for shallow waters, probably was blocked in the present Mediterranean or Panamanian regions, or both, thus preventing Atlantic deep-water oxygenation. Reefs, whose construction had kept pace with the general sea-level rise since Late Jurassic or Early Cretaceous time, probably extended north to the Grand Banks (although not necessarily as a continuous feature). Rising sea level and the shelf-edge reefs may have prevented much terrigenous debris from reaching the deep basin.

3) By Albian to Cenomanian time many of the reefs had become extinct, possibly because they could not keep pace with the rising sea level. Near the end of Cenomanian time the deep water in the North Atlantic again became oxygenated, most likely because of abyssal connections with the South Atlantic. Only pelagic red clays were deposited during the Late Cretaceous because continental detritus was trapped behind the extinct reef barriers and in extensive epicontinental and marginal seas. Moderate or low productivity and a high CCD severely restricted deposition of biogenic debris.

4) Paleocene: lowered sea level and sediment burial of reef barriers allowed terrigenous debris renewed access to the deep basin.

5) Eocene: intensified circum-equatorial circulation and relatively lowered sea level resulted in the basin being inundated by siliceous/biogenic and terrigenous debris. In the Late Eocene to early Oligocene cooler, denser water formed in the Labrador and NorwegianGreenland seas in response to cooling Tertiary climates; this denser water fed the juvenile Western Boundary Undercurrent which extensively eroded the deep continental margin and redistributed sediments throughout the basin. During the late Paleogene, siliceous skeletons settling from the surface waters were largely masked by the terrigenous debris deposited from the abyssal currents.

6) Neogene: the abyssal erosional phase continued until late Oligocene or early Miocene time when rapid deposition of terrigenous debris became dominant. The depositional phase probably occurred because of weakening bottom currents and because strong sea-level lowering allowed terrigenous debris more direct access to the deep basin. The circum-equatorial flow and its associated productivity belt ceased to exist when barriers closed the Mediterranean in the middle Miocene and formed the Isthmus of Panama in the Pliocene. Terrigenous and hemipelagic deposition have been dominant in the North Atlantic since that time.

\section{Development of Cretaceous Reefs}

At Site 384 on the $J$-Anomaly Ridge south of the Grand Banks, we drilled an upper Barremain/lower Albian, shallow-water, bioclastic limestone sequence at a depth of about 4100 meters. The limestones contain rudists and the morphology of the limestone surface in seismic profiles suggests the sequence is of reefal origin. This extends the known occurrence of such Lower Cretaceous reefs far north of those documented along the Blake Escarpment, and it lends support to the idea that the buried ridge structures beneath the eastern United States outer continental shelf also are reefs. The extinction of the reef at Site 384 in the ?Albian may be related to local subsidence of the $J$-Anomaly Ridge or to the same process that caused globally widespread extinctions at that time.

\section{Crustal Ages}

Basaltic basement was reached at three sites and was dated radiometrically (Houghton et al., this volume) and by microfossils in the overlying sediments. Basalt samples were all slightly altered, so the radiometric ages must be considered minimums. At Site 384 on the $J$ Anomaly Ridge, orbitoline foraminifers in reef debris 
immediately above basalt suggest an age of upper Barremian to lowermost Aptian (112-118 m.y.B.P.; Schroeder and Cherchi, this volume). ${ }^{40} \mathrm{Ar} / 39 \mathrm{Ar}$ and $\mathrm{K}$-Ar dating of the Site 384 basalt indicated minimum ages of $88 \pm 5 \mathrm{~m} . \mathrm{y}$. and $106 \pm 4 \mathrm{~m} . \mathrm{y}$. , respectively. The site was drilled on magnetic anomaly $M-2$ in the Keathley Sequence.

Site 386 was drilled in the Cretaceous quiet zone, 120 $\mathrm{km}$ seaward of anomaly $M-0$. Nannofossils in sediment directly overlying basalt indicate an age of early Albian (104-108 m.y.B.P.). Radiometric ages on the altered basalt range from $110 \pm 20 \mathrm{~m}$.y. to $153 \pm 18 \mathrm{~m}$.y.

Site 387 was drilled between anomalies $M-15$ and $M-16$ in the Keathley Sequence. Nannofossils indicate a late Berriasian to early Valanginian age (128-133 m.y.B.P.) for sediment found overlying the basalt and as inclusions in the basalt. The basalt is hydrothermally altered, and a gas retention age of $126 \pm 20 \mathrm{~m}$.y. is suggested.

\section{Igneous Rocks}

Igneous rocks were recovered at all sites except Site 383 , which had to be abandoned because of unstable hole conditions. Two sites yielded alkali basalt fragments in a volcaniclastic breccia (382 and 385), and three sites yielded portions of tholeiite flows ( 384 and 386 ) or sills (387) emplaced at or near the contemporary Mid-Atlantic Ridge spreading axis.

At the two sites located on the lower flanks of seamounts (382 and 385) the recovered igneous rocks are fragments of highly alkalic, light-rare-earth-enriched, vesicular basalt deposited as breccias from mass downslope flows of volcanic debris. Since both sites bottomed in breccia, neither the entire volcanogenic formation nor the underlying, pre-seamount igneous crust was sampled. The varying chemistry, vesicularity, and degree of alteration of basalt clasts suggest the debris flows incorporated fragments from a variety of eruptive events. High vesicularity of some clasts suggests both seamounts rose to within 500 meters (or less) of sea level. Radiometric and paleontological dating suggests 80 to $85 \mathrm{~m} . \mathrm{y}$. and 87 to $92 \mathrm{~m} . \mathrm{y}$. as the most probable ages of volcanism at Sites 382 and 385, respectively. Slumping and deposition of the breccias occurred concurrently with or soon after the eruptive events, and the breccias experienced non-hydrothermal cementation by epidote, zeolite, and calcite. At both seamounts two breccia zones were penetrated, separated by fine volcanogenic sediments. The existence of at least two major volcanic phases is thus suggested, separated at most by a few million years in time.

One thin $(0.18 \mathrm{~m})$ layer of aphanitic tholeiitic basalt cored within the volcanogenic formation on Vogel Seamount (Site 385) was dated at $21.0 \pm 3$ m.y.B.P. The layer apparently represents a sill of much younger age than the seamount.

At Site 384 on the crest of the $J$-Anomaly Ridge at magnetic anomaly $M-2$, portions of three altered basalt flows were cored. High vesicularity and deuteric high temperature oxidation of the basalt supports evidence from overlying bioclastic limestones that the crest of the $J$-Anomaly Ridge was initially close to sea level and at least occasionally emergent. Compositionally the basalts are typical mid-oceanic ridge tholeiites. Irontitanium enrichment or anomalously high NRM, which might explain the high amplitude " $J$-Anomaly," were not observed. However, in terms of light-rare-earth enrichment, the basalts are transitional between Icelandic or Azores basalts and the depleted rocks typifying the mid-oceanic ridge. The $J$-Anomaly Ridge at Site 384 may thus have an origin similar to the Reykjanes Ridge southwest of Iceland.

At Site 386, 9.6 meters of basalt were penetrated below lower Albian claystone. The 2.1 meters of igneous rock recovered consist of moderately chloritized, nearly or oversaturated subalkaline pillow basalt characteristic of present-day spreading centers. Compositionally similar basalt was recovered below upper Berriasian/lower Valanginian limestone at Site 387, located between anomalies $M-15$ and $M-16$. The basalt at Site 387 is fine grained and cut by vein calcite. Although structurally a sill, it was probably emplaced very close to the contemporary spreading axis.

\section{Volcanism Along the New England Seamounts}

Sites 382 and 385 were drilled to test the "stationary hot-spot hypothesis" for the origin of the New England seamount chain. Assuming that the North American plate moved at a rate of $0.38^{\circ} / \mathrm{m} . \mathrm{y}$. $(4 \mathrm{~cm} / \mathrm{yr})$ over a fixed "New England" hot spot and around a pole located at $60.7^{\circ} \mathrm{N}, 57.8^{\circ} \mathrm{E}$, we predicted Nashville Seamount (Site 382) to be about $11 \mathrm{~m} . \mathrm{y}$. younger than Vogel Seamount (Site 385). Radiometric and micropaleontological dating yielded a best estimate of 80 to 85 m.y. for the age of Nashville Seamount. The age of Vogel Seamount was less reliably placed at 87 to 92 m.y.B.P. Thus, an age difference of the magnitude predicted by the hot-spot hypothesis can be accommodated by the data. However, the various errors and uncertainties in age determination are serious enough that we cannot exclude the alternate hypothesis that Vogel and Nashville were generated coevally about 85 to 90 m.y.B.P. When Leg 43 results are combined with age dating of other seamounts and the White Mountain Magma Series in New England (presumed to be formed by the same hot spot), a stationary hot-spot hypothesis is favored, although not proven. Taken together, the data suggest that (a) the Africa plate was relatively stationary over the mantle during Mesozoic time, so that (b) motion of the North American plate over a stationary hot spot was roughly twice the spreading half rate in this region; (c) motion of the North American plate over the New England hot spot proceeded at 1.5 $\mathrm{cm} / \mathrm{yr}$ from 150 to $110 \mathrm{~m} . \mathrm{y}$. B.P., and $3.4 \mathrm{~cm} / \mathrm{yr}$ from 110 m.y.B.P. until the generation of the Corner Rise and Congress Seamount around 65 to 67 m.y.B.P. The ages given in this scenario are uncertain by at least \pm 10 per cent, and the rates of motion are certainly no more precise than \pm 50 per cent.

\section{Nature of the $J$-Anomaly}

Drilling on the $J$-Anomaly Ridge was designed to determine the nature of the basement responsible for the 
$J$-Anomaly, a linear high-amplitude magnetic anomaly located at the young end of the Keathley Sequence in the western North Atlantic. The chemistry of the igneous basement was to be analyzed to determine whether the basement ridge associated with the $J$-Anomaly, and similar features found near hot spots such as Iceland, were other than just morphologic analogs.

Because unstable sands prevented basement sampling at Site 383, a second site (384) was drilled where the $J$-Anomaly Ridge rises above the Sohm Abyssal Plain. Below a sequence of pelagic sediments, the drill encountered shallow-water bioclastic limestones at the level where igneous basement had been expected from initial inspection of seismic reflection records. At a depth of 4234 meters, 5.5 meters of altered basalt were penetrated, and 2.36 meters were recovered, representing portions of three flows.

The basalts from Site 384 are typical mid-oceanic ridge tholeiites, not anomalously high in magnetization or Fe-Ti content. Thus the recovered rocks provide no clue for the nature of the material causing the $J$-Anomaly. However, subsequent analysis of seasurface magnetic profiles shows that the zone of anomalously intense crustal magnetization responsible for the $J$-Anomaly may be centered somewhat east of the basement ridge crest actually drilled. Thus, there is no contradiction in the results, but the nature of the anomalous material remains conjectural. Analogy with other high-magnetic-amplitude ocean crust suggests $\mathrm{Fe}$-Ti-enriched basalt or ferro-gabbro as the most likely source materials.

On morphological grounds, the $J$-Anomaly Ridge and intersecting Southeast Newfoundland Ridge were suspected to have been formed by an Iceland-like hot spot centered at the junction of these ridges, just southeast of the Grand Banks. Based on analogies with Iceland and the Azores, Site 384 was drilled some distance from this hot spot. Basalts somewhat enriched in light-rare earths and LIL-elements were expected under this hypothesis, and in terms of light-rare-earth enrichment the basalts at Site 384 are transitional between strongly enriched Icelandic or Azores basalts and typically depleted mid-ocean ridge basalts. $(\mathrm{La} / \mathrm{Sm})_{E . F}$, as well as $\mathrm{TiO}_{2}, \mathrm{P}_{2} \mathrm{O}_{5}$ and $\mathrm{La}$ concentrations resemble those measured on the topographically similar Reykjanes Ridge up to $250 \mathrm{~km}$ southwest of Iceland. However, the significance of this finding is questionable because of the altered nature of the Site 384 basalt.

A basement age of 112 to 118 m.y. inferred for the $J$-Anomaly Ridge primarily from paleontological data generally agrees with geophysical evidence that the basement ridge was formed at anomaly $M-2$ time. The zone of high crustal magnetization appears to be centered between anomalies $M-0$ and $M-1$. Both the ridge, which was initially at or above sea level, and the magnetic anomaly appear to have formed at the axis of the Early Cretaceous Mid-Atlantic Ridge, and they do not represent later tectonic or igneous overprinting. This conclusion is reinforced by the existence of a mirror image $J$-Anomaly in the eastern North Atlantic.

\section{SUMMARY OF OPERATIONS}

Leg 43 began on 13 June 1975 at Istanbul, Turkey, and terminated 12 August 1975 in Norfolk, Virginia. The Challenger made a four-hour stop at Ponta Delgada, Azores, on 27 June to take aboard the scientific staff and a two-day port call at Bermuda (22-24 July) for emergency bow-thruster repairs. During the 61.4-day leg, we steamed 13,200 km; 34.7 days were spent underway, 22.9 days on site, and 3.8 days in port (Figure 3). Leg 43 statistics are given in Tables 2 and 3.

\section{Drilling and Coring}

The standard DSDP bottom-hole assembly was used at all six sites. The assembly consisted of a bit, bit sub (with float valve), core barrel, three $81 / 4$-inch drill collars, one 5-foot-stroke Baash-Ross bumper sub, three 81/4-inch drill collars, two 5-foot-stroke bumper subs, two $81 / 4$-inch drill collars, one 71/4-inch drill collar, and one joint of $51 / 2$-inch heavy-wall drill pipe.

F94CK sealed-journal-bearing roller cone bits were used at all sites, with no bit failures. All bits were recovered with bearing seals intact and bearings in good condition (Table 4). One bit was reused at three successive sites (383-385). Several tungsten carbide inserts were found broken on the Site 387 bit after it was run, and this may account for the slow penetration in basaltic basement.

The four-cone bits that were used provided generally good penetration rates in a large variety of lithofacies. Drilling rates at each site are summarized in the Site Reports, and they provide an approximate guide to formation hardness. However, drilling rates are also affected by such factors as pump pressures and weight on the bit, both of which are highly variable during the drilling history of a hole. In addition, the F94CK medium-tooth bits that were used tended to load up in claystone formations and therefore penetrated more slowly than they would in somewhat harder limestone formations.

Some difficulties were encountered with the drilling equipment. Initial problems with power to a drawworks motor and the functioning of the pipe racker skate were traced to the engine room switchboard and to a faulty control air valve, respectively, and corrected. On two occasions, malfunctions in the control components of the ELMAGCO electric drawworks brake resulted in a loss of positive braking at the driller's console.

After drilling was completed at Site 387, and as the Bowen sub-swivel assembly was to be set aside, the lower seal of the swivel failed and began leaking oil. The oil contained abundant metal fragments, indicating bearing failure in the swivel. The swivel was disassembled and the lower rate of the main (thrust) bearing was found to be severely cratered, and much of the facing metal was lost. Some of the tapered rollers were severely worn at the small end and others were pitted. Because neither a spare swivel nor spare bearing parts are carried on board, the casualty terminated drilling capabilities were terminated for the duration of the leg. 

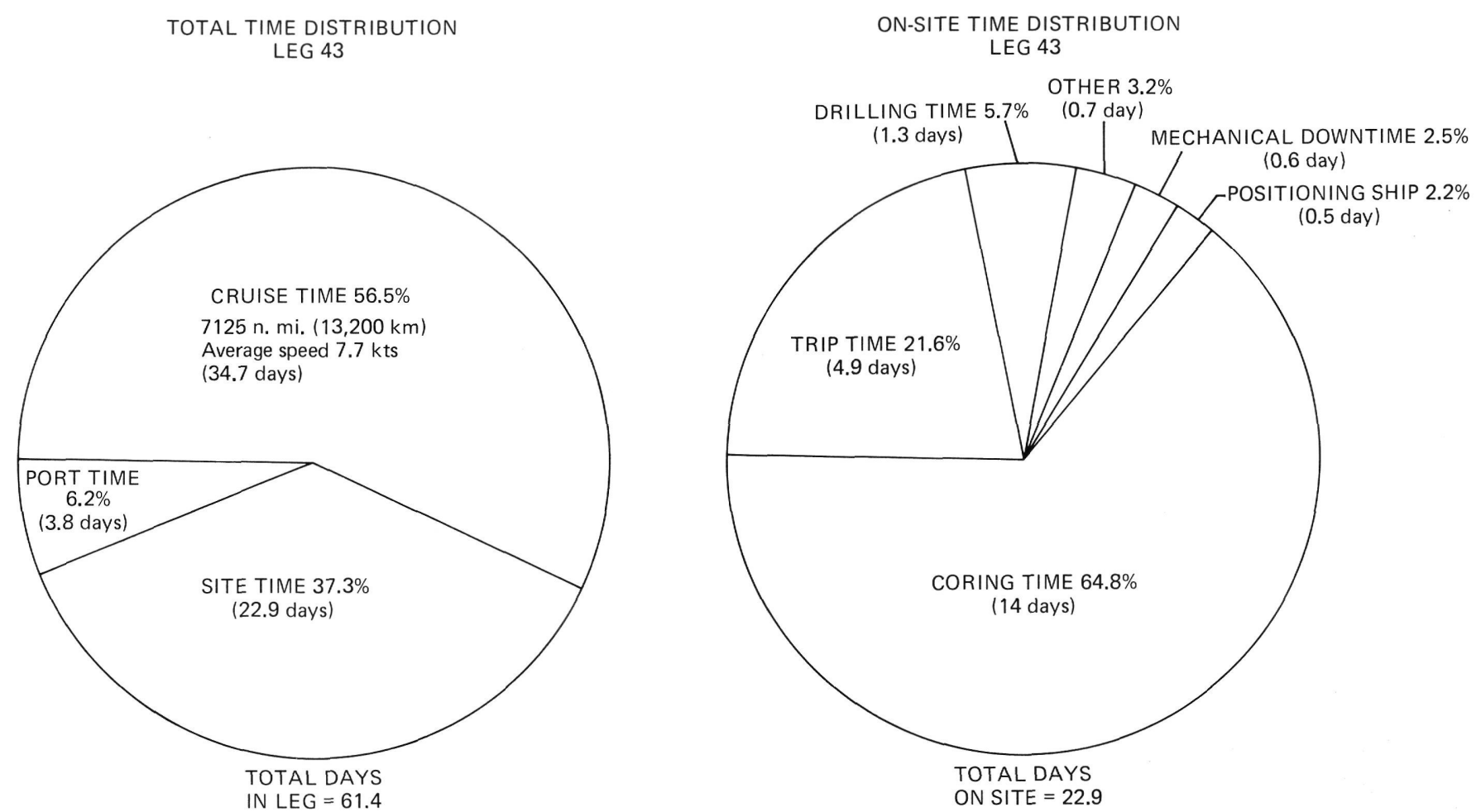

Figure 3. Total and on-site time distribution for DSDP Leg 43.

TABLE 3

Operations Statistics - Leg 43

\begin{tabular}{lr}
\hline Total Days, Leg 43 & 61.4 \\
Total Days in Port & 3.8 \\
Total Days Cruising & 34.7 \\
Total Days on Site & 22.9 \\
$\quad$ Trip Time & 4.9 \\
$\quad$ Drilling Time & 1.3 \\
Coring Time & 14.9 \\
Mechanical Downtime & 0.6 \\
$\quad$ Position Ship & 0.5 \\
Other & 0.7 \\
Total Distance Traveled (nautical miles) & 7,125 \\
Total Distance Traveled (kilometers) & 13,194 \\
Average Speed (knots) & 7.7 \\
Sites Investigated & 6 \\
Holes Drilled & 6 \\
Number of Cores Attempted & 189 \\
Number of Cores With Recovery & 184 \\
Total Meters Cored & $1,768.8$ \\
Total Meters Recovered & 958.6 \\
Percent Recovery & 54.2 \\
Total Meters Drilled & $1,363.5$ \\
Total Meters of Penetration & $3,132.3$ \\
Percent of Penetration Cored & 56.5 \\
Maximum Penetration (m) & 973.8 \\
Minimum Penetration & 120.3 \\
Maximum Water Depth (m) & 5,527 \\
Minimum Water Depth & 3,910 \\
\hline
\end{tabular}

Thus, our plans for drilling a final hole at proposed Hole 43-10 had to be abandoned.

Dog-type core catchers were used routinely in the core barrels. Occasionally, a plastic sock was inserted in the catcher to improve recovery in coarse uncon- solidated material, with marginal success. A slip-type core catcher was used unsuccessfully on two runs in basalt breccia at Site 385 .

\section{Heave Compensator}

The heave compensator was used at Site 383 and 387 to familiarize the crew with its operation for upcoming IPOD drilling and to evaluate the performance of the system.

At Site 383, during balancing procedures, the traveling block was lowered too quickly, bending the slider bar on the heave compensator, a joint of drill pipe, and a 20-foot pup joint. Damaged components were replaced, but when it was determined that the slider bar could not be repaired without excessive time loss, the heave compensator was set aside so that drilling at the site could proceed.

At Site 387, after the slider bar had been repaired, the heave compensator was used again, and it operated satisfactorily through 60 meters of penetration and one core, although the ship was heaving only very slightly. Then it was noted that the lifting block was rotating 10 to 15 degrees when the compensator cylinder was open and the drill string was being turned. The torsional force probably resulted from frictional drag in what was later found to be a deteriorating swivel thrust bearing. Repeated bending of the previously weakened slider bar and shear stress on the bolts holding it to the block could have caused failure of the bolts or of the slider bar. It therefore became necessary to remove the heave compensator from the system. 
TABLE 4

Bit Summary, DSDP Leg 43

\begin{tabular}{|c|c|c|c|c|c|c|c|c|c|c|}
\hline Hole & Mfg. & Size & Type & $\begin{array}{l}\text { Serial } \\
\text { Number }\end{array}$ & $\begin{array}{l}\text { Cored } \\
(\mathrm{m})\end{array}$ & $\begin{array}{l}\text { Drilled } \\
(\mathrm{m})\end{array}$ & $\begin{array}{c}\text { Total } \\
\text { Penetration } \\
\text { (m) }\end{array}$ & $\begin{array}{l}\text { Hours } \\
\text { on } \\
\text { Bit }\end{array}$ & Condition & Remarks \\
\hline 382 & Smith & $10-1 / 8$ & F94CK & SZ218 & 232.2 & 288.3 & 520.5 & 11.8 & $\mathrm{~T} 1, \mathrm{~B} 1, \mathrm{SE}$ & $\begin{array}{l}\text { Drilled clay and volcanic breccia; suit- } \\
\text { able for rerun }\end{array}$ \\
\hline 383 & Smith & $10-1 / 8$ & F94CK & SZ217 & 19.0 & 101.3 & 120.3 & 0.8 & $\mathrm{~T} 1, \mathrm{~B} 1, \mathrm{SE}$ & Drilled coarse, loose sand \\
\hline 384 & Smith & $10-1 / 8$ & F94CK & SZ217 & 194.4 & 135.9 & 330.3 & 8.0 & $\mathrm{~T} 1, \mathrm{~B} 1, \mathrm{SE}$ & About 3 hours in basalt; total 8.8 hours \\
\hline 385 & Smith & $10-1 / 8$ & F94CK & SZ217 & 227.9 & 164.7 & 392.6 & 10.9 & $\mathrm{~T} 1, \mathrm{~B} 1, \mathrm{SE}$ & $\begin{array}{l}\text { About } 4 \text { hours in basalt breccia; total } \\
19.7 \text { hours }\end{array}$ \\
\hline 386 & Smith & $10-1 / 8$ & F94CK & SZ087 & 626.8 & 347.0 & 973.8 & 61.1 & T1, B?, SE & $\begin{array}{l}\text { About } 5 \text { hours in basalt; core guide } \\
\text { somewhat bent }\end{array}$ \\
\hline 387 & Smith & $10-1 / 8$ & F94CK & SZ096 & 468.2 & 326.0 & 794.2 & 45.4 & T3, B?, SE & $\begin{array}{l}\text { Several broken inserts; drilled chert, } \\
\text { limestone and basalt }\end{array}$ \\
\hline
\end{tabular}

\section{Weather and Currents}

Weather during most of the cruise was excellent. Two days of rough seas and several hours delay of delay were experienced in circumnavigating tropical storm Amy while we were attempting to approach the first proposed site (Hole 43-1). Ultimately, we were forced to go south and drill proposed Hole 43-2 as our first site (Site 382) while waiting for Amy to move away from proposed Hole 43-1.

Currents caused difficulties in two instances. At Site 384, an apparent northward excursion of the Gulf Stream occurred during drilling operations. Surface currents, combined with winds and seas from the west, taxed the ship's positioning system to the extreme; the deep currents put heavy stress on the drill string and caused it to wear against the horn, generating a great deal of concern about finishing the hole. Later, while steaming from Site 384 to proposed Hole 43-6 at Gosnold Seamount, our speed over the ground was reduced to about four knots along the southern edge of the Gulf Stream, and we consequently altered our course to proceed south and drill at another seamount southeast of Gosnold Seamount (Vogel Seamount, Site 385).

\section{Navigation}

During drilling operations at Site 386, a failure of the teletypewriter printout of the satellite navigation system resulted in the loss of the satellite system for the remainder of Leg 43. An attempt was made to utilize LORAN navigation, but the unit proved to be inaccurate and unreliable. Navigation for Site 387, and for subsequent surveys and the final track to Norfolk was based on celestial fixes and dead reckoning. Due to hazy and foggy conditions at Site 387, final coordinates were based on a single star fix.

\section{EXPLANATORY NOTES}

\section{Responsibility for Authorship}

The Site Reports are authored collectively by the members of the shipboard scientific party, although the co-chief scientists have ultimate responsibility for the content of the chapters. The bulk of information and in- terpretation in the Site Reports is based on shipboard and shore-lab work of the shipboard scientists. However, we have attempted to give a complete summary of each site by incorporating, in addition, some of the results of other shore-lab investigators. These authors are cited in appropriate sections, and we thank them for their contributions to this volume.

Individual shipboard scientists were responsible for specific sections of the Site Reports as given below. This division sometimes resulted in different interpretations occurring within a single Site Report, although we have attempted to reconcile any conflicts. Responsibilities include:

Background and Objectives (B. E. Tucholke and P. R. Vogt)

Operations (B. E. Tucholke and P. R. Vogt)

Sediment Lithology and Barrel Summaries (J. Galehouse - Site 382; I. N. McCave - Sites 383, 384; R. Houghton - Site 385; P. Rothe - Site 386; I. O. Murdmaa - Site 387)

Igneous Petrology (R. Houghton)

Geochemistry (J. Kendrick)

Physical Properties (K. Demars)

Biostratigraphy (A. Kaneps - Cenozoic foraminifers, radiolarians, biostratigraphic summaries; $\mathrm{H}$. Okada - nannoplankton; C. L. McNulty Mesozoic foraminifers)

Sediment Accumulation Rates (A. Kaneps)

Correlation of Seismic Profiles with Drilling Results (B. E. Tucholke and P. R. Vogt)

Summary and Conclusions (B. E. Tucholke and P. R. Vogt).

\section{Survey and Underway Data}

The survey data which were used in selection of Leg 43 sites were provided by Lamont-Doherty Geological Observatory and the U.S. Naval Oceanographic Office. Pertinent data are given in the individual Site Reports and in a site-survey report (Bowles, this volume).

Survey and underway data acquired by Glomar Challenger during Leg 43 are presented in a separate chapter (Tucholke, this volume). Underway data acquisition included $12 \mathrm{kHz}$ echo-sounding, continuous 
seismic profiling, and measurements of the magnetic field. A map showing the Leg 43 navigation is in the cover pocket (Foldout I).

All underway data and ship tracks are annotated in Greenwich Mean Time; reference to times of this time zone have a Z (Zulu) suffix. Ship operations, drilling logs, and so forth used ship's (local) time and have no time-zone suffix.

\section{Numbering of Sites, Cores, and Samples}

Site numbers run consecutively from the first site drilled by Glomar Challenger in 1968; the site number is thus unique. A site refers to the hole or holes drilled from one acoustic positioning beacon. Several holes may be drilled at a single locality by pulling the drill string above the sea floor ("mud line") and offsetting the ship some distance (usually $100 \mathrm{~m}$ or more) from the previous hole.

The first (or only) hole drilled at a site takes the site number. Additional holes at the same site are further distinguished by a letter suffix. The first hole has only the site number, the second has the site number with suffix $\mathrm{A}$, the third has the site number with suffix B, and so forth. For example, if three holes had been drilled at Site 382 they would be referenced as Site 382 (first hole), Hole 382A (second hole), and Hole 382B (third hole). It is important, for sampling purposes, to distinguish the holes drilled at a site, since recovered sediments usually do not come from equivalent positions in the stratigraphic column at different holes.

Cores are numbered sequentially from the top down. In the ideal case, they consist of 9.5 meters of sediment or rock of $6.6 \mathrm{~cm}$ diameter. In addition, a short sample is obtained from the core catcher (a multifingered device at the bottom of the core barrel which prevents cored materials from sliding out during core-barrel recovery). This core-catcher sample usually contains about $20 \mathrm{~cm}$ of sediment or rock. During Leg 43 the core-catcher sample was split (if possible), described, and stored along with the rest of the core, taking care to maintain its proper vertical orientation. This sample represents the lowest stratum recovered in a particular cored interval. The core-catcher sample is designated by CC (e.g., $382-4, \mathrm{CC}$; CC is the core-catcher sample of the fourth core taken at Site 382).

The cored interval is the interval in meters below the sea floor measured from the point at which coring for a particular core was started to the point at which it was terminated. This interval is generally 9.5 meters (nominal length of a core barrel) but may be shorter or longer if conditions dictate. Cores (or cored intervals) need not be contiguous. In soft sediment, the drill string can be "washed ahead" without recovering core by applying sufficiently high pump pressure to wash sediment out of the way of the bit. In a similar manner, a center bit, which fills the opening in the bit face, can replace the core barrel if drilling ahead in hard sediments without coring is necessary.
When a core is brought aboard the Glomar Challenger, it is labeled, and the plastic liner and core are cut into 1.5-meter sections (Figure 4a). A full, 9.5-meter core would thus consist of six sections, numbered from the top down, 1 to 6 . Generally, something less than 9.5 meters is recovered. In this case, the sections are still numbered starting with Section 1 at the top, but the number of sections is the number of 1.5 -meter intervals needed to accommodate the length of core recovered; this is illustrated in Figure 4b-d).

Thus, as shown, recovery of 5.7 meters of sediment would result in a core with four sections, with a void of 0.3 meters at the top of the first section (Figure $4 b$ ). By convention, and for convenience in routine data handling at the Deep Sea Drilling Project, if a core contains a length of material less than the length of the cored interval, the recovered material is placed in the top of the cored interval, with the top of Section 1, rather than the top of the sediment, equal to the top of the cored interval.

A discrepancy exists between the usual coring interval of 9.5 meters and the length of the conventional six 1.5-meter sections which comprise 9 meters. The core liners used are actually 9.28 meters in length, and the core catcher accounts for another 0.2 meter. In cases where the core liner is recovered full to the top, the core is still cut into six 1.5-meter sections measured from the bottom of the liner, and the extra 0.28 -meter section at the top is designated Section 0, or the "Zero Section" (Figure 4A). On Leg 43, all zero sections were split and described. In the case of cores with zero sections, depth below sea floor is calculated by placing the top of Section 0 at the top of the cored interval. The depth of the core-catcher sample is calculated by placing it immediately below the lowermost section recovered (Figure 4b-d).

In the core laboratory on Glomar Challenger after routine processing, the 1.5 -meter sections of sediment core and liner are split in half lengthwise. One half is designed the "archive" half, which is described by the shipboard geologists and photographed; and the other is the "working" half, which is sampled by the shipboard sedimentologists and paleontologists for further shipboard and shore-based analysis.

Samples taken from core sections are designated by the interval in centimeters from the top of the core section from which the sample was extracted; the sample size, in $\mathrm{cm}^{3}$, is also given. Thus, a full sample designation would consist of the following information:

Leg (Optional)

Site (Hole, if other than first hole)

Core

Section

Interval in centimeters from top of section.

Site $382-3-2,122-124 \mathrm{~cm}\left(10 \mathrm{~cm}^{3}\right)$ designates a $10 \mathrm{cc}$ sample taken from Section 2 of Core 3 from the first hole drilled at Site 382. The depth below the sea floor for this sample would then be the depth to the top of the 
CORE LABELING

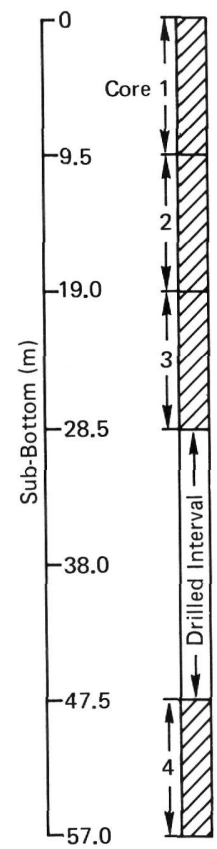

CORE SECTION LABELING

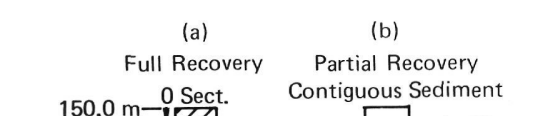

Partial Recovery

Separated Fragments
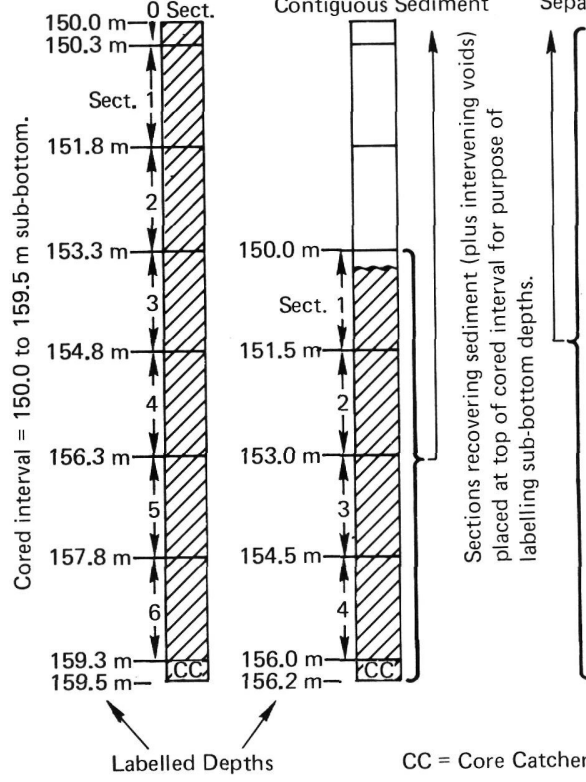

(c)

(d)

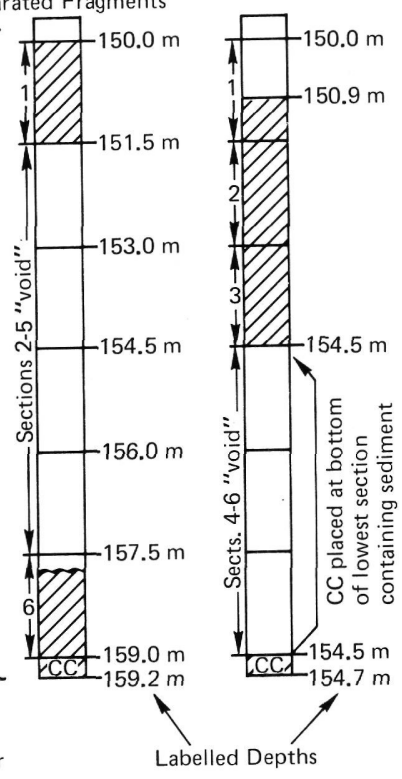

Figure 4. Conventions for numbering of core sections and placement of recovered sediment in cored interval.

cored interval (174 meters) plus 1.5 meters for Section 1, plus $122 \mathrm{~cm}$ (depth below the top of Section 2), or 176.7 meters. Note, however, that sample requests should refer to a specific interval within a core section (in $\mathrm{cm}$ ) rather than depth in meters below the sea floor.

\section{Requests for DSDP Samples}

Sediment cores obtained during Leg 43 are in cold storage at the DSDP East Coast Repository, LamontDoherty Geological Observatory. Investigators wishing to obtain samples are directed to the DSDP-NSF Sample Distribution Policy at the end of this chapter. Sample requests must be submitted on standard DSDP request forms which may be obtained from:

The Curator

Deep Sea Drilling Project A-031

University of California, San Diego

La Jolla, California 92093

\section{Handling of Cores}

Before the cores are split, they are routinely subjected to Gamma Ray Attenuation Porosity Evaluator (GRAPE) Analysis to determine saturated bulk density and porosity. 10 - to 20 -centimeter sections also are cut from the bottom of some core sections and put in cold storage for later geochemical and interstitial-water analyses; these samples therefore were not described on the ship. Selected cores with visually undisturbed sediment were allowed to equilibrate to room temperature, and thermal conductivity measurements were made.

Splitting of cores on Leg 43 was normally accomplished in one of two ways. For unconsolidated sedi- ments, the plastic liner was cut in the core-lab "guillotine" and the sediment then split and separated longitudinally with a knife or cheese cutter. For consolidated sediments, the entire core including the plastic liner was sawed in half using a water-cooled diamond saw.

The archive half of each core was used for the visual core description and subsequently was photographed. Although every attempt was made to "anchor" loose core material in the liner of both archive and working halves with tape and styrofoam inserts, there undoubtedly are instances where material, when photographed, was displaced in the liner from the level at which it was described. This disturbance can become more severe when the cores are shipped to the core repository. Investigators obtaining samples or examining cores from the repository should keep this problem in mind.

The working halves of the cores were subjected to shipboard measurements of shear strength and sonic velocity (Hamilton Frame) before being sampled for grain-size, carbon-carbonate, X-ray mineralogy, bulk physical properties, and paleontological analyses. Smear slides from major (and many minor) lithologic facies were prepared and examined microscopically to provide data on texture and composition.

At several sites, samples of basaltic basement rocks were obtained. Each fragment in these cores was numbered and labeled sequentially from the top down and its orientation indicated by an upward-pointing arrow. These cores were not split, but cylindrical samples were obtained from fragments by using a rock drill. These samples were subsequently used for thin sectioning, and 
for shore-lab studies of magnetization, velocity, and radiometric age.

The combined results of shipboard and shore-lab analyses of the samples described above serve as the basis for the visual core descriptions presented in the Site Reports.

\section{Core Descriptions}

Descriptions and photographs of cores recovered during Leg 43 are presented in the Site Reports (Chapters 2-7). A summary of the kinds of data in the core descriptions (Figure 5) follows.

\section{Graphic Lithology and Sedimentary Structures}

Symbols depicting lithologic types and sedimentary structure are shown in Figure 6.

\section{Drilling Disturbance and Downhole Contamination}

Unconsolidated sediments often are disturbed by the rotary drilling/coring technique, and there is a gradation in disturbance style and intensity with decreasing sediment induration. An assessment of degree and style of drilling deformation is made onboard ship for all cored material, and shown graphically on the core description sheets. The symbols used are shown in Figure 7. Consolidated sediments and rocks seldom show much internal deformation, but are usually broken by drilling into cylindrical pieces of varying length. There is frequently no indication whether such adjacent pieces in the core liner are actually contiguous or if intervening sediment was lost during drilling. These sediments are marked as weakly deformed or as cylindrical segments $(0-0-0)$.

Downhole contamination occurs when sediment falls, is dragged, or is washed to a lower stratigraphic position and then is cored. Displaced manganese nodules and other large, solid fragments at the top of a core can usually be recognized as downhole contamination. Other material may be more difficult to recognize as such unless it is distinguished as an overlying lithology or contains younger fossils. Where downhole contaminants are recognized, they are so marked on the core descriptions.

\section{Lithologic Samples}

Depths are marked in the "Lithology Sample" column where samples were taken for smear-slide analysis. Geochemical samples, where complete core segments were removed, are marked across the core as "OG" (organic geochemistry) or "IW" (interstitial water).

Locations of other samples (grain-size, X-ray mineralogy, carbon carbonate, etc.) are given in appropriate tables and chapters in this volume.

\section{Carbon-Carbonate Data}

During Leg 43, extensive use was made of the carbonate bomb device (Müller and Gaster, 1971) as an aid in sediment classification. This device is basically a cylindrical vessel with pressure gage, in which a sediment sample of known weight is reacted with acid. The pressure of $\mathrm{CO}_{2}$ generated is measured and converted to per cent carbonate. Accuracy to within \pm 3 per cent total carbonate usually can be obtained. Shipboard carbonate bomb data are listed in a separate column on the core description sheet.

Samples also were taken for DSDP shore-based carbon-carbonate analysis using the LECO 70-second Analyzer. Procedures are outlined in Volumes 9 and 18 of the Initial Reports of the Deep Sea Drilling Project. These results also are listed on the core description sheet and are distinguished from carbonate bomb values by italic type. Organic carbon-content values obtained in the LECO analyses are presented in Appendix IV, this volume. Accuracy and precision of the LECO results are:

$$
\begin{array}{lll}
\text { Total Carbon } & \pm 0.3 \% & \text { (absolute) } \\
\text { Organic Carbon } & \pm 0.06 \% & \text { (absolute) } \\
\mathrm{CaCO}_{3} & \pm 3 \% & \text { (absolute) }
\end{array}
$$

\section{Sediment Name}

A description of the sediment classification system used on Leg 43 is given later in this chapter.

\section{Color}

Color notations are based on the standard Munsell or GSA color charts. Colors were determined during shipboard description of the freshly split cores. Commonly, colors of sediments that are rich in organic matter or chemically reduced components will fade or disappear after extended exposure to air during storage. Colors particularly susceptible to fading are purple, light and medium blues, light blue-gray, dark greenish black, light green and pale orange. These colors fade to whites, off-whites, and cream-tans.

\section{Smear Slides}

The lithologic classification of sediments is based on visual estimates of texture and composition in smear slides made on board ship. These estimates are of areal abundances on the slide and may differ somewhat from the more accurate laboratory analyses of grain size, carbonate content, and mineralogy. Experience has shown that distinctive minor components can be accurately estimated ( \pm 1 or $2 \%$ ), but that an accuracy of \pm 10 per cent for major constituents is rarely attained. Carbonate content is especially difficult to estimate in smear slides (although it was often checked against bomb results), as is the amount of clay present. Smear-slide analyses averaged for intervals of uniform lithology are given on the core description sheets. For carbonate content, refer to the shipboard carbonate bomb analyses and shorebased analyses.

\section{X-Ray Mineralogical Analyses}

X-ray mineralogical analyses of Leg 43 sediments were conducted by Peter Rothe of the Leg 43 shipboard party and by Roman Koch, and results are tabulated in a separate chapter (Koch and Rothe, this volume). The percentages of constituent minerals are summed to 100 per cent and are normalized to per cent carbonate as determined by the carbonate bomb technique. The clay- 


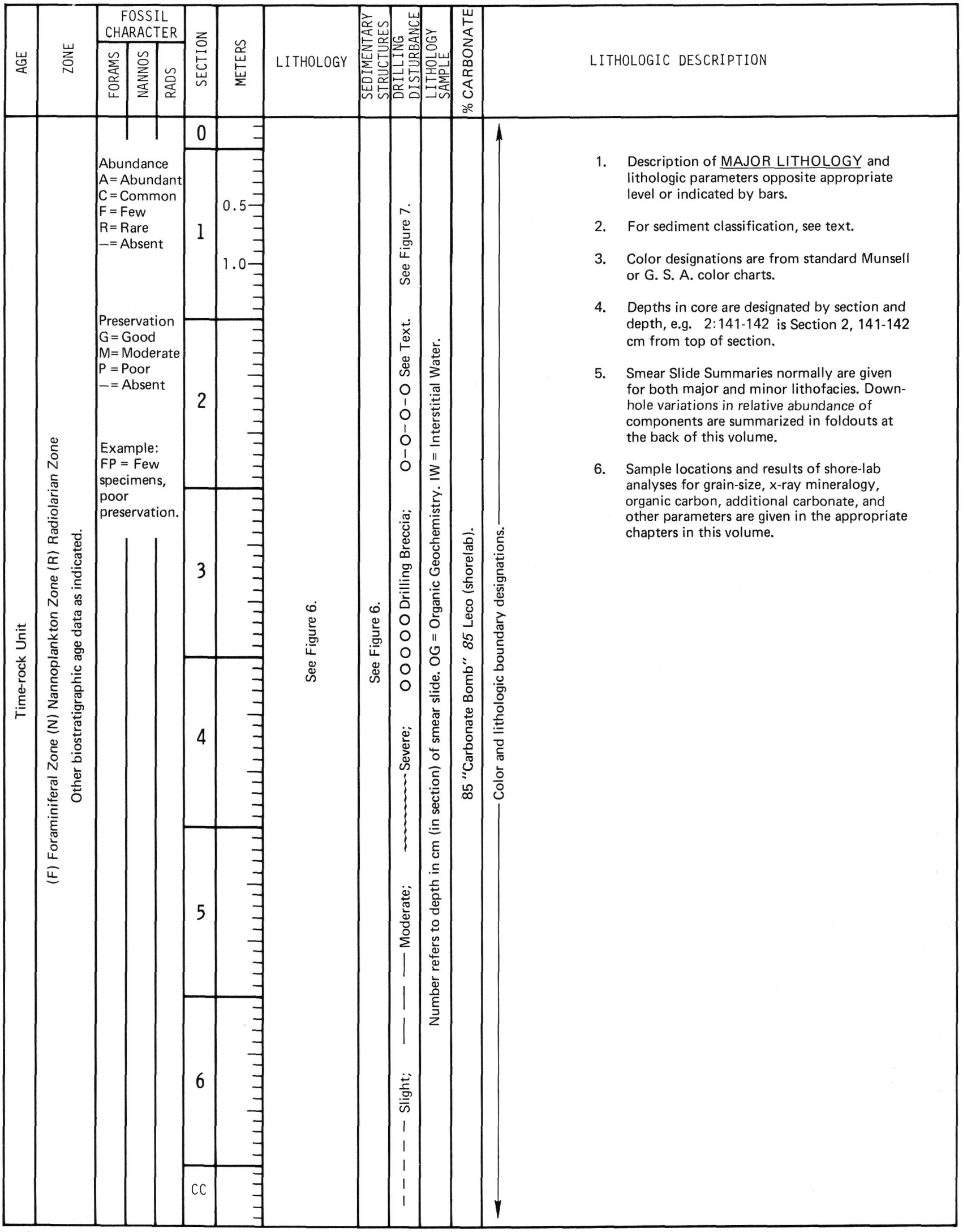

Explanatory notes in Chapter 2

Figure 5. Visual core description format with explanatory notes. 
Parallel lamination and/or sharp color/ lithofacies contacts

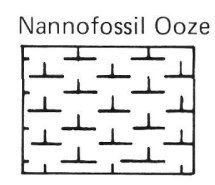

Nanno-Foram or Foram-Nanno Chalk

Diffuse lamination and color/lithofacies contacts

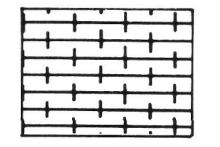

Burrow mottling
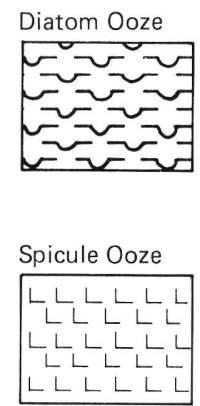

Cross-

bedding

Graded

bedding

○

Erosional

fill)
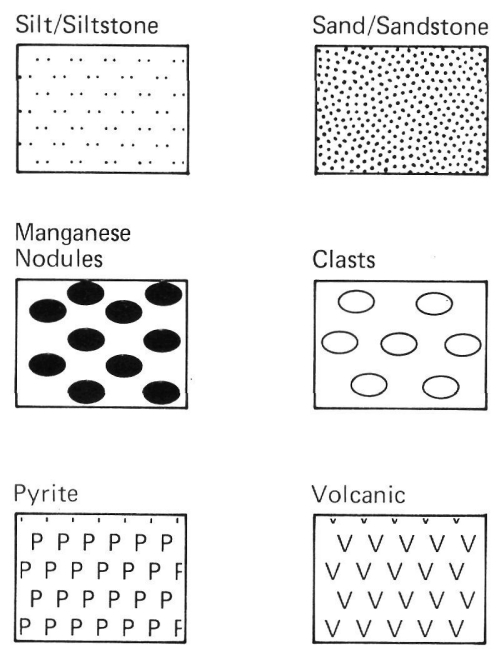

LITHOLOGIC SAMPLE SYMBOLS

$$
\begin{aligned}
& 65= \text { Smear slide depth } \\
& \text { in section in cm } \\
& O G= \text { Organic Geochemistry } \\
& \text { IW }=\text { Interstitial Water }
\end{aligned}
$$
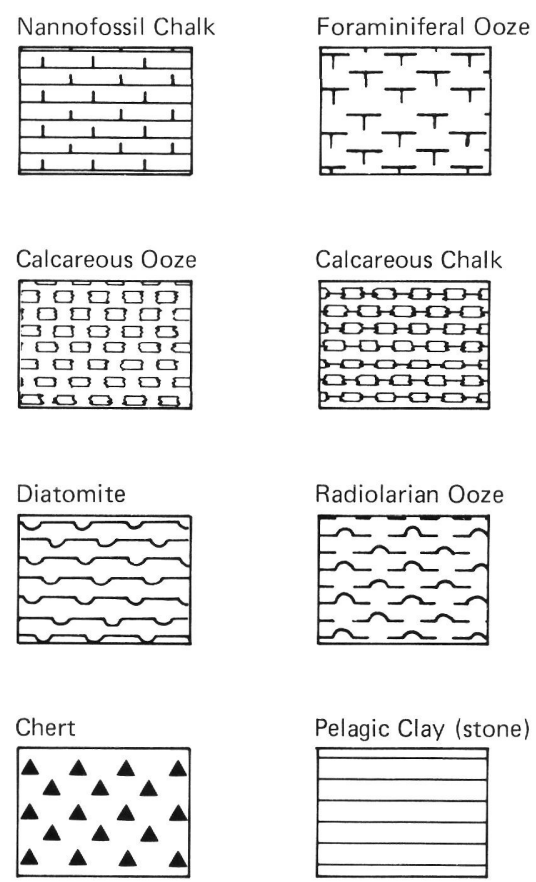

Volcaniclastic
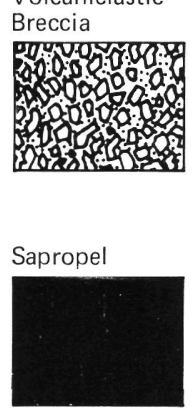

Foraminiferal Chalk
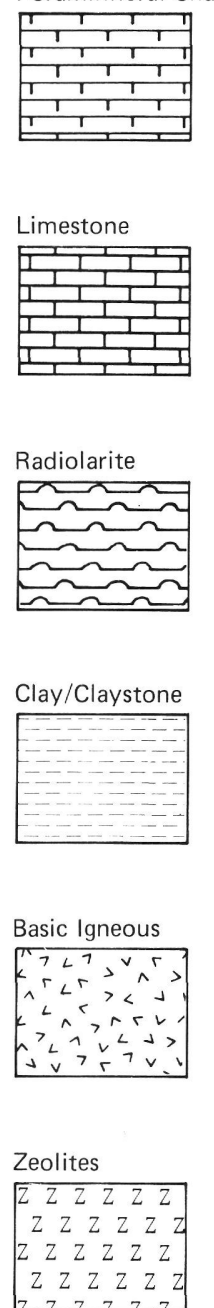

Nanno-Foram or

Foram-Nanno Ooze
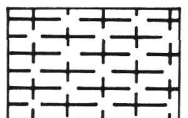

Reef Limestone

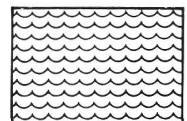

Diatom-Rad or Siliceous Ooze
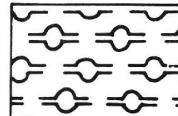

Clayey Silt/Silty Clay/Mud (stone)
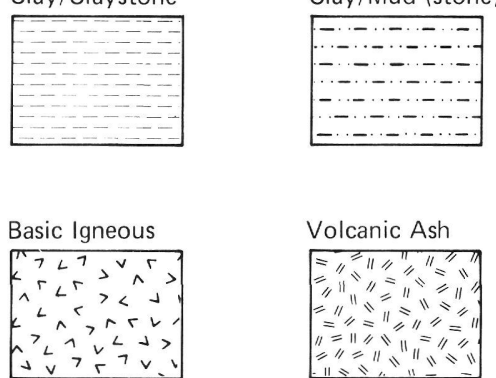

Siderite

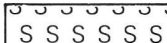

S S S S S S

S S S S S S

S S S S S S S

Figure 6. Lithology symbols and symbols used to depict primary sedimentary structures.

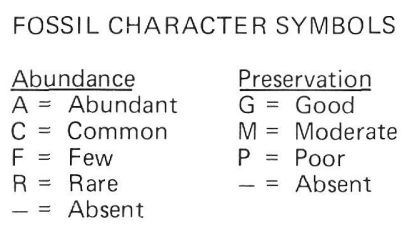

(Example: $\mathrm{CM}=$ common specimens, moderate preservation).

\section{$\%$ CARBONATE}

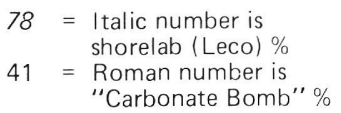

$78=$ Italic number is shorelab (Leco) \%

$41=$ Roman number is

"Carbonate Bomb" \%

BIOSTRATIGRAPHIC ZONES

$(F)=$ Foraminifers

$(\mathrm{N})=$ Nannoplankton

$(\mathrm{R})=$ Radiolarians 
DRILLING DISTURBANCE

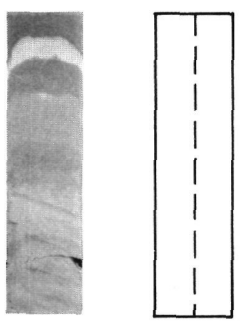

SLIGHTLY DEFORMED; bedding contacts slightly bent.

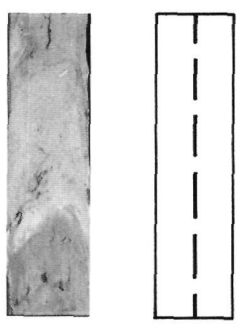

MODERATELY DEFORMED; bedding contacts extremely bowed.

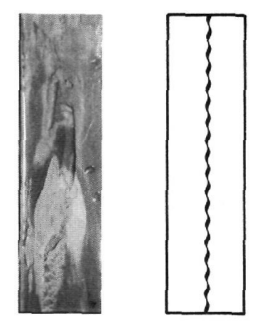

HIGHLY DEFORMED; bedding completely disturbed, often showing symmetrical diapir-like structures.

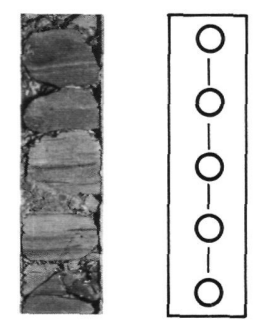

SEGMENTS of solid core SEPARATED BY DRILLING BRECCIA.

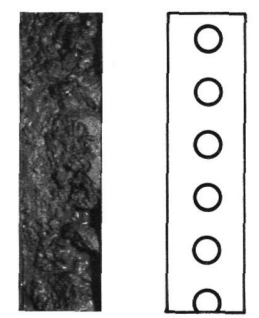

DRILLING SLURRY or DRILLING BRECCIA; water-saturated intervals which have lost all aspects of original bedding and sediment cohesiveness.

Figure 7. Symbols used to depict core disturbance.

mineral composition of the $<2 \mu \mathrm{m}$ fraction is also given. Where necessary, these results have been used by the Leg 43 sedimentologists to correct smear-slide determinations and to change sediment names from the original shipboard description.

\section{Sediment Induration}

The determination of induration is highly subjective, but field geologists have successfully made similar distinctions for many years. The criteria of Moberly and Heath (1971) are used for calcareous deposits; subjective estimates or behavior in core cutting is used for others.

a) Calcareous sediments

Soft: Oozes have little strength and are readily deformed under the broad blade of a spatula.

Firm: Chalks are partly indurated oozes; they are friable limestones that are readily deformed under the fingernail or the edge of a spatula blade.

Hard: Cemented rocks are termed limestones.

b) The following criteria are used for other sediments:

If the material is soft enough that the core can be split with a wire cutter, the sediment name only is used (e.g., silty clay; sand).

If the core must be cut on the band saw or diamond saw, the suffix "stone" is used (e.g., silty claystone; sandstone).

\section{Sediment Classification}

The sediment classification scheme used on Leg 43 is basically that devised by the JOIDES Panel on Sedimentary Petrology and Physical Properties and adopted for use by the JOIDES Planning Committee in March 1974, with minor modifications. The classification is outlined below.

A) Sediment assumes the names of those components present only in quantities greater than 15 per cent.

B) Where more than one component is present, the component in greatest abundance is listed farthest to the right, and other components are listed progressively to the left in order of decreasing abundance.

C) The class limits are based on percentage intervals given below for various sediment types.

\section{Pelagic Clay $>10 \%$ authigenic components \\ $<30 \%$ siliceous microfossils \\ $<30 \% \mathrm{CaCO}_{3}$ \\ $<30 \%$ terrigenous components}

2. Pelagic Siliceous Biogenic Sediments

$>30 \%$ siliceous microfossils

$<30 \% \mathrm{CaCO}_{3}$

$<30 \%$ terrigenous components (mud)

Radiolarians dominant: radiolarian ooze (or radiolarite).

Diatoms dominant: diatom ooze (or diatomite).

Sponge spicules dominant: sponge spicule ooze (or spiculite).

Where uncertain: siliceous (biogenic) ooze (or chert, porcelanite)

When containing 10-30 per cent $\mathrm{CaCO}_{3}$ : modified by nannofossil---------, foraminiferal---------, cal- 
careous---------, nannofossil-foraminiferal---------, or foraminiferal-nannofossil---------, . . . depending upon kind and quantity of $\mathrm{CaCO}_{3}$ component.

3. Transitional Biogenic Siliceous Sediments

$10-70 \%$ siliceous microfossils

$30-90 \%$ terrigenous components (mud) $<30 \% \mathrm{CaCO}_{3}$

If diatoms < mud: diatomaceous mud (stone). If diatoms > mud: muddy diatom ooze (muddy diatomite).

If $\mathrm{CaCO}_{3}$ 10-30 per cent: appropriate qualifier is used (see 2).

4. Pelagic Biogenic Calcareous Sediments

$>30 \% \mathrm{CaCO}_{3}$

$<30 \%$ terrigenous components

$<30 \%$ siliceous microfossils

Principal components are nannofossils and foraminifers; qualifiers are used as follows:

\begin{tabular}{|c|c|}
\hline Foram $(\%)$ & Name \\
\hline$<10$ & $\begin{array}{l}\text { nannofossil ooze (chalk, } \\
\text { limestone) }\end{array}$ \\
\hline $10-25$ & foraminiferal-nannofossil ooze \\
\hline $\begin{array}{l}25-50 \\
>50\end{array}$ & $\begin{array}{l}\text { nannofossil-foraminiferal ooze } \\
\text { foraminiferal ooze }\end{array}$ \\
\hline
\end{tabular}

Calcareous sediment containing 10-30 per cent siliceous fossils carry the qualifier radiolarian, diatomaceous or siliceous depending upon the identification.

5. Transitional Biogenic Calcareous Sediments $>30 \% \mathrm{CaCO}_{3}$

$>30 \%$ terrigenous components

$<30 \%$ siliceous microfossils

If $\mathrm{CaCO}_{3}$ 30-60 per cent: marly is used as a qualifier:

soft: marly calcareous (or nannofossil, etc.) ooze firm: marly chalk (or marly nannofossil chalk, etc.)

hard: marly limestone (or marly nannofossil limestone, etc.)

If $\mathrm{CaCO}_{3}>60$ per cent:

soft: calcareous (or nannofossil, etc.) ooze

firm: chalk (or nannofossil chalk, etc.)

hard: limestone (or nannofossil limestone, etc.)

NOTE: Sediments containing 10-30 per cent $\mathrm{CaCO}_{3}$ fall in other classes where they are denoted with the adjective "calcareous," "nannofossil", etc.

6. Terrigenous Sediments
$>30 \%$ terrigenous components
$<30 \% \mathrm{CaCO}_{3}$
$<10 \%$ siliceous microfossils
$<10 \%$ authigenic components

Sediments in this category are subdivided into textural groups on the basis of the relative proportions of three grain-size components, i.e., sand, silt and clay. Sediments coarser than sand-size are treated as "Special Rock Types". The size limits are those defined by Wentworth (1922). The textural classification is according to the triangular diagram of Shepard (1954) (Figure 8). The suffix

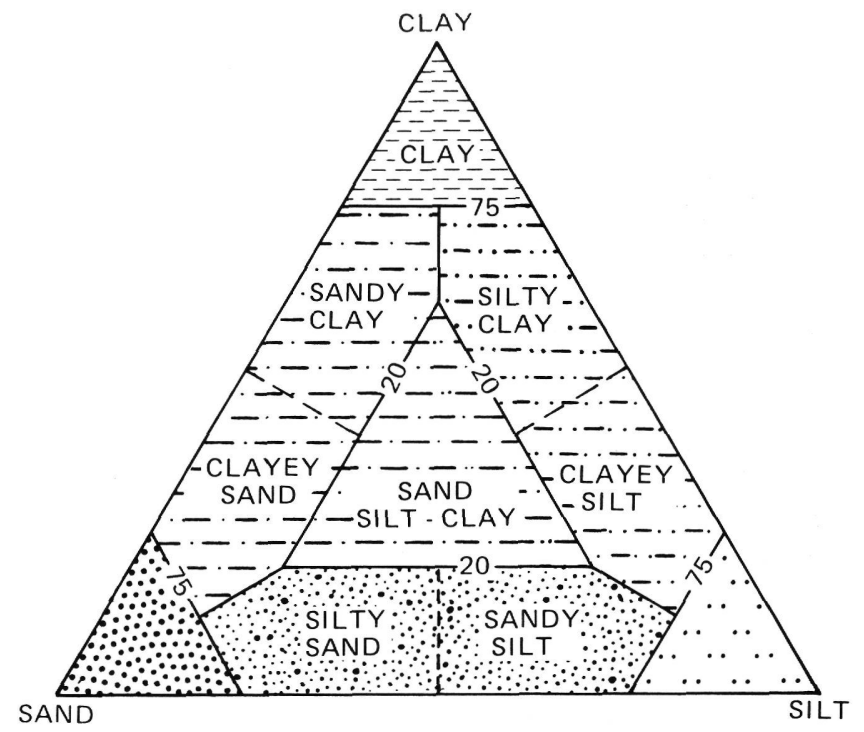

Figure 8. Shepard's (1954) texture diagram.

"-stone" is used to indicate hard or consolidated equivalents of the unconsolidated sediments.

If $\mathrm{CaCO}_{3}$ is $10-30$ per cent: calcareous, nannofossil, etc., is used as a qualifier.

Other qualifiers (e.g., feldspathic, glauconitic, etc.) are used for components $>10$ per cent.

7. Volcanogenic Sediments

a) Pyroclastic rocks are described according to the textural and compositional scheme of Wentworth and Williams (1932). The textural groups are:

Volcanic breccia $\quad>32 \mathrm{~mm}$

Volcanic lapilli $\quad 4-32 \mathrm{~mm}$

Volcanic ash (tuff, if indurated) $<4 \mathrm{~mm}$

Compositionally, these pyroclastic rocks are described as vitric (glass), crystal or lithic.

b) Clastic sediments of volcanic provenance are described in the same fashion as the terrigenous sediments, noting the dominant composition of the volcanic grains where possible.

8. Special Rock Types

a) Volcanogenic sediments cored at Sites 382 and 385 include units with clastic volcanic components $>32 \mathrm{~mm}$ in size that appear to have been displaced to deep water by gravitational processes and which may include pyroclastic debris. These rocks are referred to as "volcaniclastic breccias."

b) Limestones cored at Site 384 contain shallowwater reefal debris with a variety of calcite cements. These bioclastic limestones are classified according to the format of Folk (1962, 1968).

\section{Basis for Age Determinations}

The biostratigraphic schemes for planktonic foraminifers, nannofossils, and radiolarians employed during Leg 43 are shown in Figure 9. Only those biostratigraphic intervals actually recovered during the leg are 
shown. Correlation with the scale of absolute time is essentially that of Berggren (1972), with the exception of the Paleocene. This part of the time scale is based on the combined biostratigraphic/paleomagnetic studies of the Gubbio section in Italy, and the suggested correlation of this sequence with the revised sea-floor-anomaly time scale (La Breque et al., 1977; Kent, 1976). This results in compressing the Paleocene zones into a considerably shorter time interval than in the Berggren (1972) scale, and also produces an artificially large gap between the Paleocene and Eocene zones sampled during Leg 43. This is a matter yet to be resolved by further age dating in the lower Tertiary and adjustment of zonal boundaries. The time scale used for the Cretaceous and Jurassic stages is that of van Hinte (1976).

\section{Geochemistry}

During the cruise, alkalinity, $p \mathrm{H}$, and salinity were measured routinely on interstitial water samples squeezed from soft sediments with a hydraulic press similar to that described by Manheim (1966). As a check on possible contamination, surface sea water, which during drilling is circulated through the drill string, was also analyzed. Detailed descriptions of equipment and procedures are given in the Explanatory Notes of DSDP Volume 23.

Briefly, analytical methods are as follows:

1) Alkalinity - A potentiometric titration with $0.1 \mathrm{~N}$ $\mathrm{HCl}$ on a $10-\mathrm{ml}$ aliquot of interstitial water was conducted.

2) $p \mathrm{H}-p \mathrm{H}$ was determined on the alkalinity sample prior to concentration.

3) Salinity-Salinity is determined from the fluid refractive index measured in a Goldberg optical refractometer, according to:

$$
\text { Salinity }(\%)=0.55(\Delta \mathrm{N})
$$

Where $\Delta \mathrm{N}=$ refractive index difference $\times 10^{4}$. Local sea water serves as a reference.

\section{Physical Properties}

A discussion of the methods of physical properties analysis is given by K. Demars in the Physical Properties section of the Site 382 Report. Measurements on Leg 43 included the following:

1) Gamma Ray Attenuation Porosity Evaluator (GRAPE) measurements of bulk density and porosity. Detailed discussions of this technique are given by Boyce $(1973,1976)$ and are not repeated here. The GRAPE results are presented in the Physical Properties table of each Site Report and in Appendix V.

2) Thermal conductivities were determined on numerous cores during Leg 43 , but the raw data have not been reduced. Results will be published in a future volume (A. Erickson, personal communication, 1976).

3) Shear strength

4) Sonic velocity

5) Water content

6) Impedance

\section{7) Triaxial-compression tests}

8) Uniaxial-compression tests.

The results and methods of analysis for 3 through 8 above are presented in the Site Reports and by Demars et al. (this volume).

\section{SAMPLE DISTRIBUTION POLICY}

\section{Deep Sea Drilling Project/International Phase of Ocean Drilling}

Distribution of Deep Sea Drilling samples for investigation will be undertaken in order to (1) provide supplementary data to support Glomar Challenger scientists in achieving the scientific objectives for their particular cruise, and in addition to serve as a mechanism for contributions to the Initial Reports; (2) provide individual investigators with materials to conduct detailed studies beyond the scope of the Initial Reports; and (3) provide the reference centers where paleontologic materials are stored with samples for reference and comparison purposes.

The National Science Foundation has established a Sample Distribution Panel to advise on the distribution of core materials. This panel is chosen in accordance with usual Foundation practices, in a manner that will assure advice in the various disciplines leading to a complete and adequate study of the cores and their contents. Funding for the proposed research must be secured separately by the investigator. It cannot be provided through the Deep Sea Drilling Project.

The Deep Sea Drilling Project's Curator is responsible for distributing the samples and controlling their quality, as well as preserving and conserving core material. He also is responsible for maintaining a record of all samples that have been distributed, shipboard and subsequent, indicating the recipient, and the nature of the proposed investigation. This information is made available to all investigators of DSDP materials as well as other interested researchers on request.

The distribution of samples is made directly from one of the two existing repositories, Lamont-Doherty Geological Observatory and Scripps Institution of Oceanography, by the Curator or his designated representative.

1. Distribution of Samples for Research Leading to Contributions to Initial Reports

Any investigator who wishes to contribute a paper to a given volume of the Initial Reports may write to the Chief Scientist, Deep Sea Drilling Project (A-031), Scripps Institution of Oceanography, University of California at San Diego, La Jolla, California 92093, U.S.A., requesting samples from a forthcoming cruise. Requests for a specific cruise should be received by the Chief Scientist TWO MONTHS in advance of the departure of the cruise in order to allow time for the review and consideration of all requests and to establish a suitable shipboard sampling program. The request should include a statement of the nature of the study proposed, size and approximate number of samples required to complete the study, and any particular sampling technique or equipment that might be required. The requests will be reviewed by the Chief Scientist of the Project and the cruise cochief scientists; approval will be given in accordance with the scientific requirements of the cruise as determined by the appropriate JOIDES Advisory Panel(s). If approved, the requested samples will be taken, either by the shipboard party if the workload permits, or by the curatorial staff shortly following the return of the cores to the repository. Proposals must be of a scope to ensure that samples can be processed and a contribution completed in time for publication in the Initial Reports. Except for rare, specific instances involving ephemeral properties, sampling will not exceed one-quarter of the volume of core recovered, with no interval being depleted and one-half of all core being retained as an archive. Shipboard sampling shall not exceed approximately 100 igneous samples per investigator; in all cases cochief scientists are requested to keep sampling to a minimum.

The co-chief scientists may elect to have special studies of selected core samples made by other investigators. In this event the names of these investigators and complete listings of all materials loaned or distributed must be forwarded, if possible, prior to the cruise or, as soon as possible following the cruise, to the Chief Scientist through the DSDP Staff Science Representative for that particular cruise. In such cases, all requirements of the Sample Distribution Policy shall also apply. 


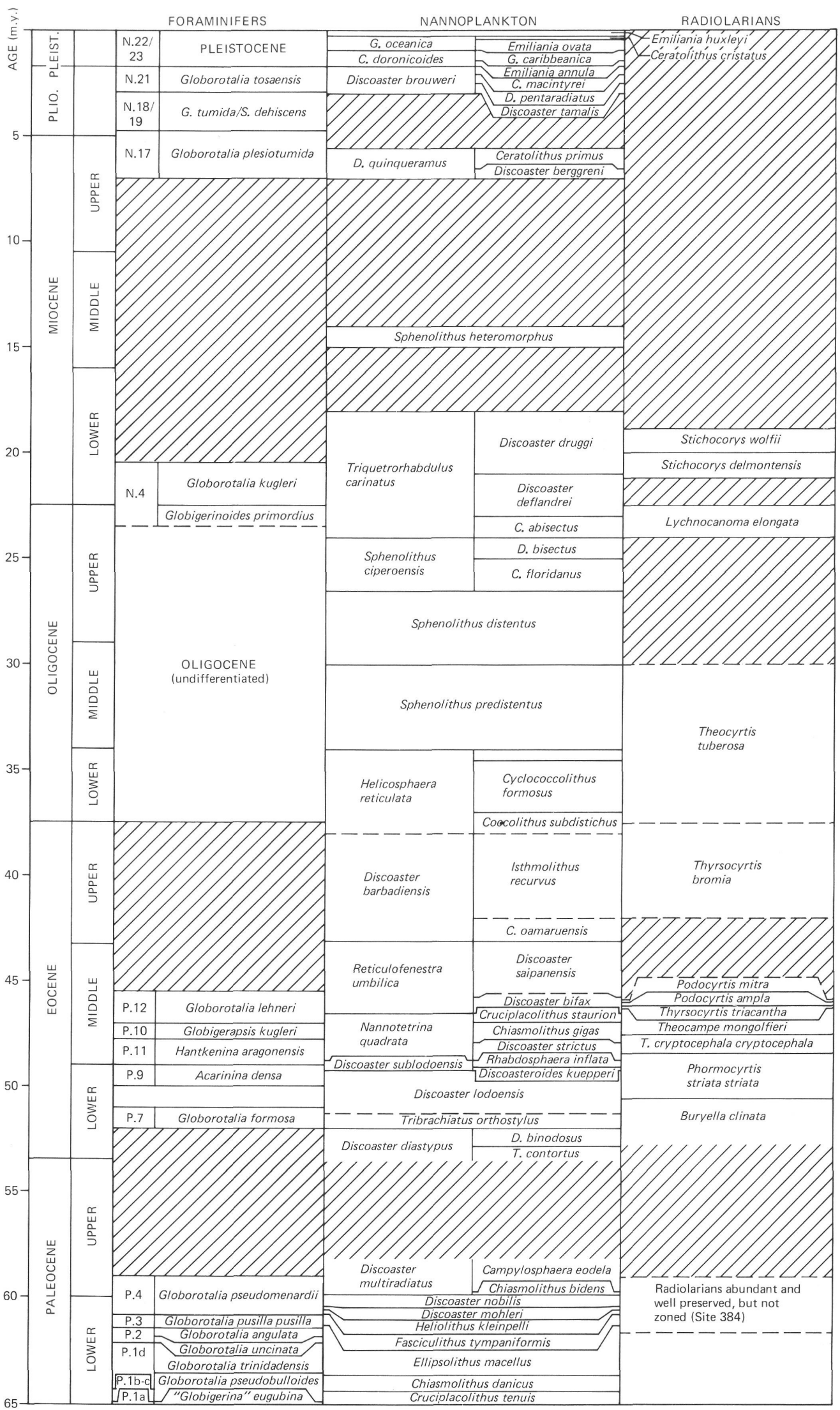

Figure 9. Biostratigraphic zonation and time scale used on Leg 43. 


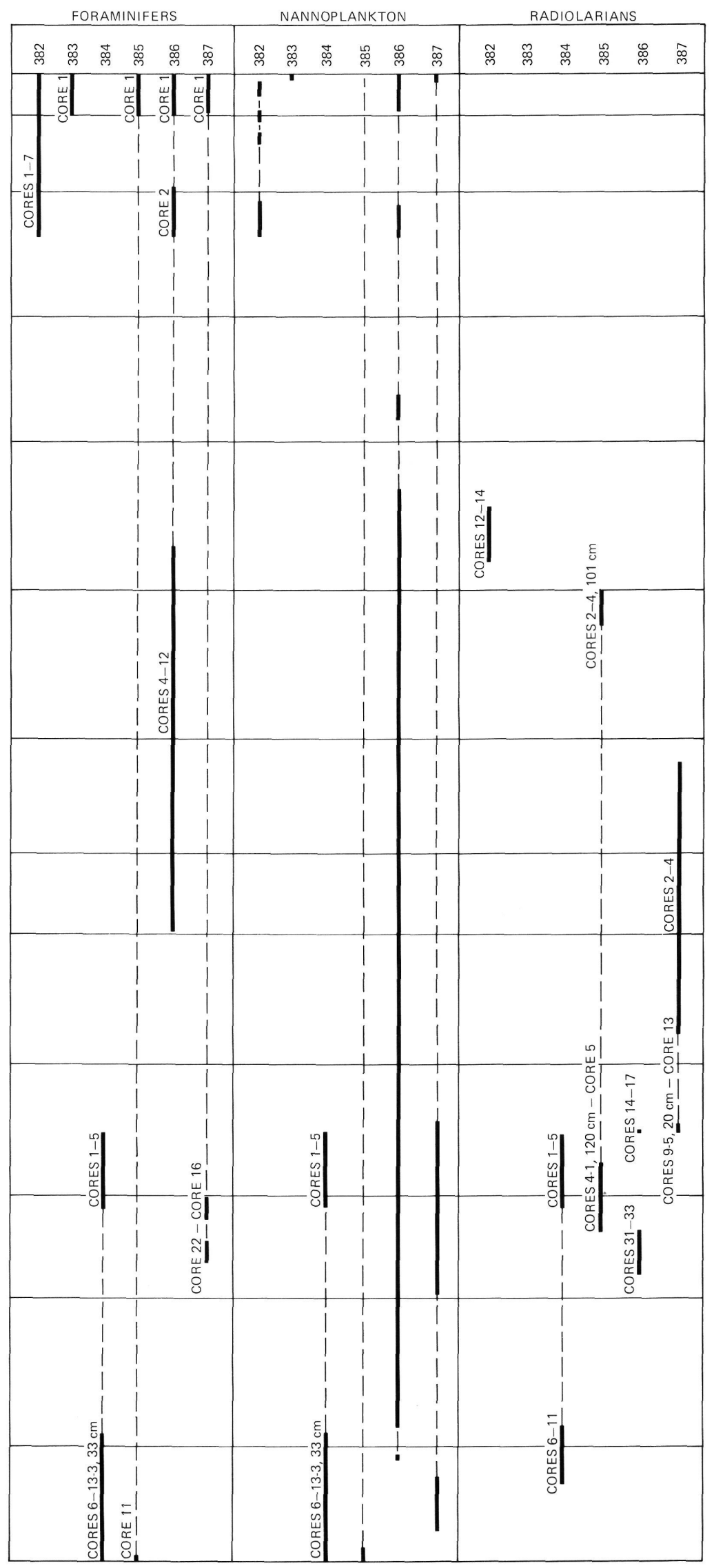

Figure 9. (Continued). 
If a dispute arises or if a decision cannot be reached in the manner prescribed, the NSF Sample Distribution Panel will conduct the final arbitration.

Any publication of results other than in the Initial Reports within twelve (12) months of the completion of the cruise must be approved and authored by the whole shipboard party and, where appropriate, shore-based investigators. After twelve months, individual investigators may submit related papers for open publication provided they have submitted their contributions to the Initial Reports. Investigations not completed in time for inclusion in the Initial Reports for a specific cruise may not be published in other journals until final publication of that Initial Report for which it was intended. Notice of submission to other journals and a copy of the article should be sent to the DSDP Chief Science Editor.

\section{Distribution of Samples for Research Leading to Publication} Other Than in Initial Reports

A. Researchers intending to request samples for studies beyond the scope of the Initial Reports should first obtain sample request forms from the Curator, Deep Sea Drilling Project (A-031), Scripps Institution of Oceanography, University of California at San Diego, La Jolla, California 92093, U.S.A. On the forms the researcher is requested to specify the quantities and intervals of the core required, make a clear statement of the proposed research, state time required to complete and submit results for publication, specify the status of funding and the availability of equipment and space foreseen for the research.

In order to ensure that all requests for highly desirable but limited samples can be considered, approval of requests and distribution of samples will not be made prior to 2 months after publication of the Initial Core Descriptions (I.C.D.). ICD's are required to be published within 10 months following each cruise. The only exceptions to this policy will be for specific instances involving ephemeral properties. Requests for samples can be based on the Initial Core Descriptions, copies of which are on file at various institutions throughout the world. Copies of original core logs and data are kept on open file at DSDP and at the Repository at Lamont-Doherty Geological Observatory, Palisades, New York. Requests for samples from researchers in industrial laboratories will be handled in the same manner as those from academic organizations, with the same obligation to publish results promptly.

B. (1) The DSDP Curator is authorized to distribute samples up to $50 \mathrm{ml}$ per meter of core. Requests for volumes of material in excess of this amount will be referred to the NSF Sample Distribution Panel for review and approval. Experience has shown that most investigations can be accomplished with 10-ml-sized samples or less. All investigators are encouraged to be as judicious as possible with regard to sample size and, especially, frequency within any given core interval. The Curator will not automatically distribute any parts of the cores which appear to be in particularly high demand; requests for such parts will be referred to the Sample Distribution Panel for review. Requests for samples from thin layers or important stratigraphic boundaries will also require Panel review.

(2) If investigators wish to study certain properties which may deteriorate prior to the normal availability of the samples, they may request that the normal waiting period not apply. All such requests must be reviewed by the curators and approved by the NSF Sample Distribution Panel.

C. Samples will not be provided prior to assurance that funding for sample studies either exists or is not needed. However, neither formal approval of sample requests nor distribution of samples will be made until the appropriate time (Item A). If a sample request is dependent, either wholly or in part, on proposed funding, the Curator is prepared to provide to the organization to whom the funding proposal has been submitted any information on the availability (or potential availability) of samples that it may request.

D. Investigators receiving samples are responsible for:

(1) publishing significant results; however, contributions shall not be submitted for publication prior to 12 months following the termination of the appropriate leg;
(2) acknowledging, in publications, that samples were supplied through the assistance of the U.S. National Science Foundation and others as appropriate;

(3) submitting five (5) copies (for distribution to the Curator's file, the DSDP Repositories, the Glomar Challenger's Library, and the National Science Foundation) of all reprints of published results to the Curator, Deep Sea Drilling Project (A-012), Scripps Institution of Oceanography, University of California at San Diego, La Jolla, California 92093, U.S.A.;

(4) returning, in good condition, the remainders of samples after termination of research, if requested by the Curator.

E. Cores are made available at repositories for investigators to examine and to specify exact samples in such instances as may be necessary for the scientific purposes of the sampling, subject to the limitations of B (1 and 2) and D, above, with specific permission of the Curator or his delegate.

F. Shipboard-produced smear slides of sediments and thin sections of indurated sediments, igneous and metamorphic rocks, will be returned to the appropriate repository at the end of each cruise or at the publication of the Initial Reports for that cruise. These smear slides and thin sections will form a reference collection of the cores stored at each repository and may be viewed at the respective repositories as an aid in the selection of core samples.

G. The Deep Sea Drilling Project routinely processes by computer most of the quantitative data presented in the Initial Reports. Space limitations in the Initial Reports preclude the detailed presentation of all such data. However, copies of the computer readout are available for those who wish the data for further analysis or as an aid in selecting samples. A charge will be made to recover expenses in excess of $\$ 50.00$ incurred in filling requests.

\section{Other Records}

Magnetics, seismic reflection, downhole logging, and bathymetric data collected by the Glomar Challenger will also be available for distribution at the same time samples become available.

Requests for data may be made to:

Associate Chief Scientist, Science Services

Deep Sea Drilling Project (A-031)

Scripps Institution of Oceanography

University of California at San Diego

La Jolla, California 92093

A charge will be made to recover the expenses in excess of $\$ 50.00$ in filling individual requests. If required, estimated charges can be furnished before the request is processed.

\section{Reference Centers}

As a separate and special category, samples will be distributed for the purpose of establishing up to five reference centers where paleontologic materials will be available for reference and comparison purposes. The first of these reference centers has been approved at Basel, Switzerland.

\section{REFERENCES}

Berggren, W. A., 1972. A Cenozoic time scale: some implications for regional geology and paleobiogeography, Lethaia, v. 5, p. 195-215.

Boyce, R. E., 1973. Appendix I. Physical property methods. In Edgar, N. T., Saunders, J. B., et al., Initial Reports of the Deep Sea Drilling Project, v. 15: Washington (U.S. Government Printing Office), p. 1115-1128.

1976. Definitions and laboratory techniques of compressional sound velocity parameters and wet-water content, wet-bulk density, and porosity parameters by gravimetric and gamma ray attenuation techniques. In Schlanger, S. O., Jackson, E. D., et al., Initial Reports of the Deep Sea Drilling Project, v. 33: Washington (U.S. Government Printing Office), p. 931-958. 
Ewing, J. I. and Hollister, C. D., 1972. Regional aspects of deep sea drilling in the western North Atlantic. In Hollister, C. D., Ewing, J. I., et al., Initial Reports of the Deep Sea Drilling Project, v. 11: Washington (U.S. Government Printing Office), p. 951-973.

Folk, R. L., 1962. Spectral subdivision of limestone types. In Ham, W. E. (Ed.), Classification of carbonate rocks: Am. Assoc. Petrol. Geol. Mem. 1, p. 62-84.

1968. Petrology of sedimentary rocks: Austin, Texas (Hemphills).

Kent, D. V., 1977. An estimate of the duration of the faunal change at the Cretaceous-Tertiary boundary, Geology, v. 5, p. 769-771.

La Breque, J. L., Kent, D. V., and Cande, S. C., 1977. Revised magnetic polarity time scale for the Late Cretaceous and Cenozoic, Geology, v. 5, p. 330-335.

Manheim, F. T., 1966. A hydraulic squeezer for obtaining interstitial water from consolidated and unconsolidated sediments, U.S. Geol. Surv. Prof. Paper 550-C, p. 256.

Moberly, R., Jr. and Heath, G. R., 1971. Carbonate sedimentary rocks from the Western Pacific: Leg 7, Deep Sea Drill- ing Project. In Winterer, E. L., Reidel, W. R., et al., Initial Reports of the Deep Sea Drilling Project, v. 7, Part 2: Washington (U.S. Government Printing Office), p. $977-$ 985.

Muller, G. and Gastner, M., 1971. The “'Karbonat-Bombe," a simple device for the determination of the carbonate content in sediments, soils, and other materials, $N$. $J b$. Miner. Mh., v. 10, p. 466-469.

Shepard, F. P., 1954. Nomenclature based on sand-silt-clay ratios, J. Sediment. Petrol., v. 24, p. 151-158.

van Hinte, J. E., 1976a. A Jurassic time scale, Am. Assoc. Petrol. Geol. Bull., v. 60, p. 489-497.

1976b. A Cretaceous time scale, Am. Assoc. Petrol. Geol. Bull., v. 60, p. 498-516.

Wentworth, C. K., 1922. A scale of grade and class terms of clastic sediments, J. Geol., v. 30, p. 377.

Wentworth, C. K. and Williams, H., 1932. The classification and terminology of the pyroclastic rocks, Rept. Comm. Sed., Nat. Res. Council, Bull., no. 89, p. 19-53. 